\title{
THE CIVILIAN IRREGULAR DEFENSE GROUP: BEHIND THE DECISION TO CHANGE OPERATIONAL CONTROL
}

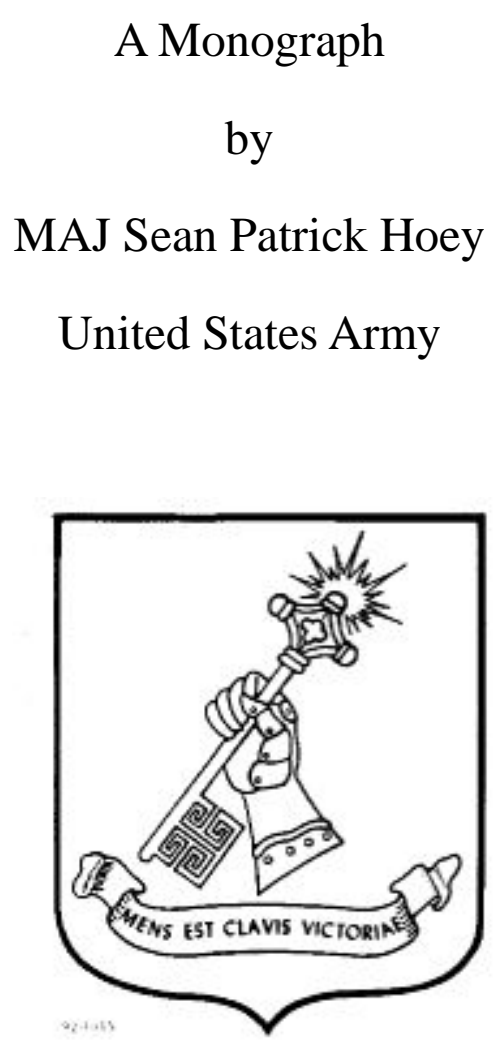

School of Advanced Military Studies

United States Army Command and General Staff College

Fort Leavenworth, Kansas

AY 2014-001 


\section{REPORT DATE (DD-MM-YYYY) \\ 22-05-2014 \\ 2. REPORT TYPE SAMS Monograph}

4. TITLE AND SUBTITLE

The Civilian Irregular Defense Group: Behind the Decision to Change

Operational Control
3. DATES COVERED (From - To) June 2013 - May 2014

5a. CONTRACT NUMBER

5b. GRANT NUMBER

5c. PROGRAM ELEMENT NUMBER

6. AUTHOR(S)

Major Sean Patrick Hoey, U.S. Army

5d. PROJECT NUMBER

5e. TASK NUMBER

5f. WORK UNIT NUMBER

\author{
7. PERFORMING ORGANIZATION NAME(S) AND ADDRESS(ES) \\ School of Advanced Military Studies (SAMS) \\ 250 Gibbon Ave \\ Fort Leavenworth, KS 66027-2301
}

8. PERFORMING ORGANIZATION REPORT NUMBER

9. SPONSORING/MONITORING AGENCY NAME(S) AND ADDRESS(ES)

U.S. Army Command and General Staff College

ATTN: ATZL-SWD-GD

100 Stimson Ave.

Ft. Leavenworth, KS 66027-2301
10. SPONSOR/MONITOR'S ACRONYM(S) SAMS

11. SPONSORING/MONITORING AGENCY REPORT NUMBER

\title{
12. DISTRIBUTION AVAILABILITY STATEMENT
}

Approved for public release; distribution is unlimited.

\section{SUPPLEMENTARY NOTES}

\section{ABSTRACT}

This study examines the decision process that led to the change of operational control of the CIDG program in Vietnam from the CIA to the MACV under Operation Switchback. The method of analysis includes discussion of the mechanics of the NSC and JCS, the changes wrought by the Kennedy Administration, the effects of the Bay of Pigs and Cuban Missile Crisis upon the administration's view of the military leadership of the time, and the practical implications of administering the CIDG program that occurred within this atmosphere that led to the change. The study shows that the effect of these actions was the loss of the only Pacification force designed and trained to conduct missions with indigenous personnel until the institution of the CORDS program in 1967 and the creation of RF/PFs. The study demonstrates that the decision to change operational control of the program was clearly grounded in interpersonal biases between senior civilian and military leadership rather than measures of military effectiveness.

\section{SUBJECT TERMS}

Vietnam, Civilian Irregular Defense Group, Operation Switchback, Kennedy Administration, Joint Chiefs of Staff, Central Intelligence Agency, Bay of Pigs, Operation Zapata, Cuba Study Group, Cuban Missile Crisis

\begin{tabular}{|c|c|c|c|c|c|}
\hline \multicolumn{3}{|c|}{ 16. SECURITY CLASSIFICATION OF: } & \multirow{2}{*}{$\begin{array}{l}\text { 17. LIMITATION OF } \\
\text { ABSTRACT } \\
\text { (U) }\end{array}$} & \multirow{2}{*}{$\begin{array}{l}\text { 18. NUMBER } \\
\text { OF PAGES } \\
60\end{array}$} & \multirow{2}{*}{$\begin{array}{l}\text { 19a. NAME OF RESPONSIBLE PERSON } \\
\text { 19b. TELEPONE NUMBER (Include area code) }\end{array}$} \\
\hline $\begin{array}{l}\text { a. REPORT } \\
(U)\end{array}$ & $\begin{array}{l}\text { b. ABSTRACT } \\
(U)\end{array}$ & $\begin{array}{l}\text { c. THIS PAGE } \\
(U)\end{array}$ & & & \\
\hline
\end{tabular}




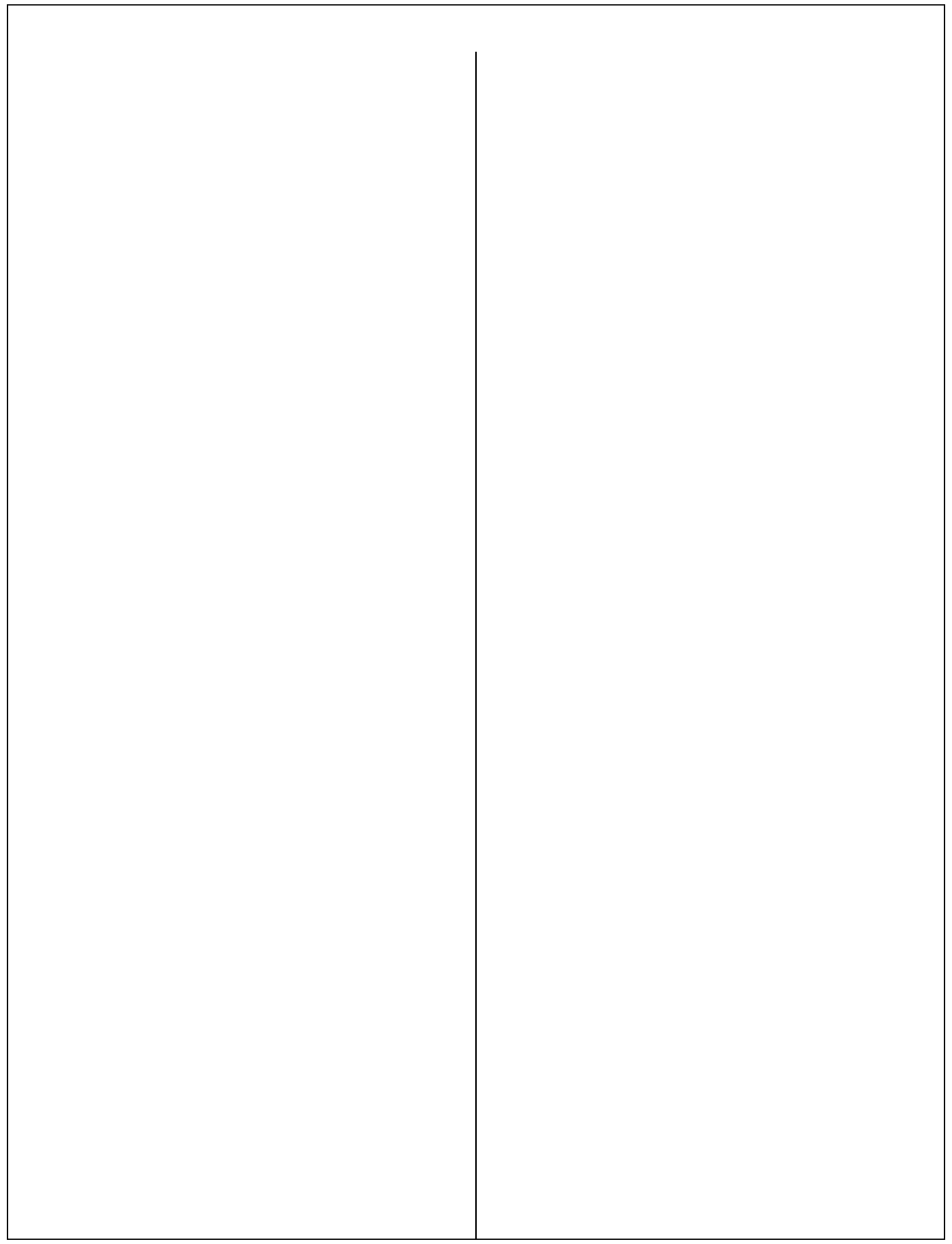

STANDARD FORM 298 Back (Rev. 8/98) 


\section{MONOGRAPH APPROVAL}

Name of Candidate: MAJ Sean P. Hoey

Monograph Title: THE CIVILIAN IRREGULAR DEFENSE GROUP: BEHIND THE DECISION TO CHANGE OPERATIONAL CONTROL

Approved by:

Barry M. Stentiford, Ph.D. , Monograph Director

Christopher T. Drew, COL, EN Seminar Leader

Henry A. Arnold III, COL, IN

, Director, School of Advanced Military Studies

Accepted this $22^{\text {nd }}$ day of May 2014 by:

Robert F. Baumann, Ph.D.

, Director, Graduate Degree Programs

The opinions and conclusions expressed herein are those of the student author, and do not necessarily represent the views of the U.S. Army Command and General Staff College or any other government agency. (References to this study should include the foregoing statement.) 


\begin{abstract}
THE CIVILIAN IRREGULAR DEFENSE GROUP: BEHIND THE DECISION TO CHANGE OPERATIONAL CONTROL, by MAJ Sean P. Hoey, United States Army, 50 pages.

This study examines the decision process that led to the change of operational control of the CIDG program in Vietnam from the CIA to the MACV under Operation Switchback. The method of analysis includes discussion of the mechanics of the NSC and JCS, the changes wrought by the Kennedy Administration, the effects of the Bay of Pigs and Cuban Missile Crisis upon the administration's view of the military leadership of the time, and the practical implications of administering the CIDG program that occurred within this atmosphere that led to the change. The study shows that the effect of these actions was the loss of the only Pacification force designed and trained to conduct missions with indigenous personnel until the institution of the CORDS program in 1967 and the creation of RF/PFs. The study demonstrates that the decision to change operational control of the program was clearly grounded in interpersonal biases between senior civilian and military leadership rather than measures of military effectiveness.
\end{abstract}




\section{ACKNOWLEDGEMENTS}

To the little girl who gave up so much and asked only that I write about the Bear Family somewhere in my "Big Paper.” I would like to thank the Bear Family for their forbearance and unshakeable support throughout the year long saga that encompassed the crafting of this document. First and foremost MamaBear, I would like to thank her for understanding the many violations of standing Den policy that were required to make this happen. I would like to thank BabyBear for her understanding of the missed days at Snow Creek and lost opportunities for rough housing, as well as the time spent listening to and learning more about military history at the dinner table than they ever wanted to know. 


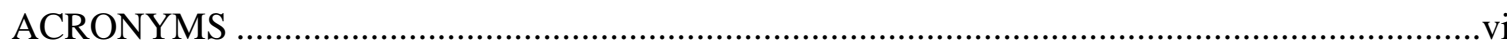

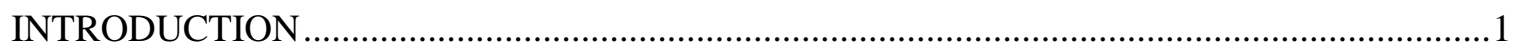

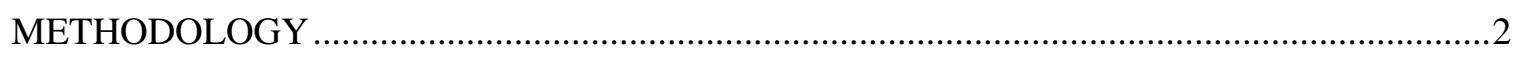

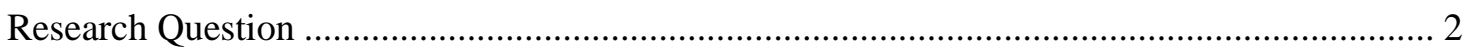

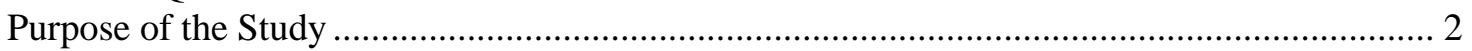

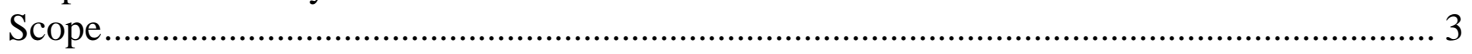

Literature Review and Purpose of Study …..................................................................... 4

THE CIVILIAN IRREGULAR DEFENSE GROUP AND OPERATION SWITCHBACK ........13

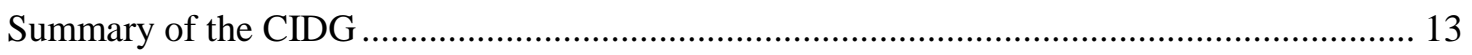

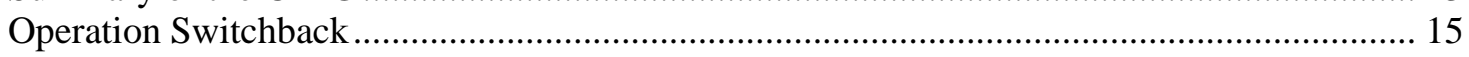

EFFECTS OF THE MOVEMENT OF THE CIVILIAN IRREGULAR DEFENSE GROUP ......18

CIVIL/MILITARY LEADERSHIP RELATIONS LEAD TO CHANGE ..................................20

The Kennedy Administration: Policy-Making Is Politics ................................................... 20

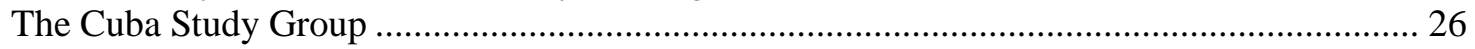

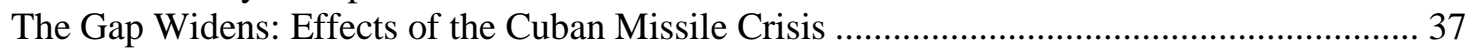

Practical Application Supports Movement ....................................................................... 41

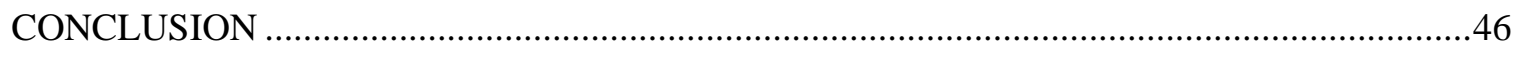

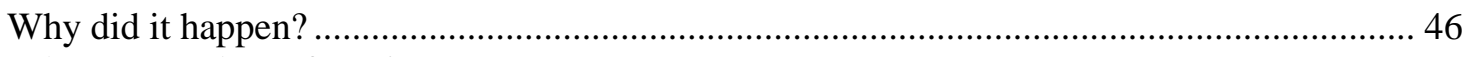

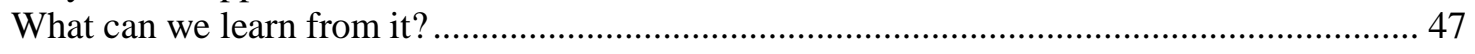

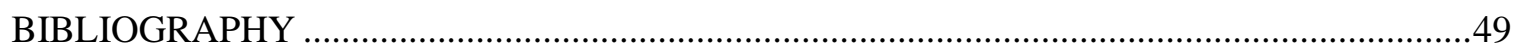




\section{ACRONYMS}

\begin{tabular}{|c|c|}
\hline ARVN & Army of the Republic of Vietnam \\
\hline CIA & Central Intelligence Agency \\
\hline CIDG & Civilian (Citizen) Irregular Defense Group \\
\hline COIN & Counterinsurgency \\
\hline CORDS & Civil Operations and Revolutionary Development Support (Vietnam) \\
\hline CSD & Combined Studies Division \\
\hline CSG & Cuba Study Group \\
\hline DOD & Department of Defense \\
\hline GVN & A military acronym for the Government of Vietnam that actually refers to the \\
\hline & Republic of Vietnam government \\
\hline JCS & Joint Chiefs of Staff \\
\hline MAAG & Military Assistance Advisory Group (aka USMAAG) \\
\hline MACV & Military Assistance Command Vietnam (aka COMUSMACV) \\
\hline MKE & Mobile Strike \\
\hline NLF & National Liberation Front (aka. Viet Cong, Vietnam) \\
\hline NSAM & National Security Action Memorandum \\
\hline NSC & National Security Council \\
\hline NVA & North Vietnamese Army \\
\hline OPCON & Operational Control \\
\hline OSS & Office of Strategic Services \\
\hline $\mathrm{RF} / \mathrm{PF}$ & Regional Force / Popular Force \\
\hline SECDEF & Secretary of Defense \\
\hline SFODA & Special Forces Operational Detachment - Alpha \\
\hline SRG & Strategic Resources Group \\
\hline
\end{tabular}


Viet Cong (common name for the NLF in South Vietnam) 


\section{INTRODUCTION}

Very often policy is the sum of a congeries of separate or only vaguely related actions...Sometimes policies are formulated and duly ratified only to be skewed to an entirely different direction and purpose by those carrying them out...

- Roger Hilsman, To Move a Nation: The Politics of Foreign Policy in the Administration of John F. Kennedy

A decision that changed the course of the Vietnam War was made based upon internal political factors rather than measures of military effectiveness. The Civilian Irregular Defense Group (CIDG) was created through experimentation to win the populace of Vietnam back from the insurgency. The CIDG was a Central Intelligence Agency (CIA) program that grew and became unwieldy for that organization and was placed beneath the conventional Military Assistance Command Vietnam (MACV) leadership. The decision to adjust operational control of the CIDG program changed the only successful counterinsurgency (COIN) force in Vietnam into a counterguerilla force. The reasons for this change were a mix of politics and practicality whose outcome would alter the nature of the fighting of the Vietnam war until the institution of the Civil Operations and Revolutionary Development Support (CORDS) program. The Vietnam War was a fight to win the people of South Vietnam, yet internal political factors, not military analysis, was used to determine the future of the most effective force specifically designed to do just that. The choice, and the path that led to the decision described in this monograph, carries implications for every future civilian and military decision maker. They must ask themselves: Is this best for the mission, or best for the decision-makers? 


\section{METHODOLOGY}

\section{Research Question}

This monograph answers whether or not the decision to change operational control of the CIDG from CIA to conventional military control under the MACV was based in an assessment that this would increase the program's military efficacy or if other factors were responsible for the decision. The history of the CIDG's movement from a CIA experiment, to a highly successful Special Forces endeavor, to its subsequent movement from CIA control to the MACV, which immediately changed the CIDG's mission from counterinsurgency to counter-guerilla operations, prompted the question: What were the effects of this movement upon the counterinsurgency mission in Vietnam? The movement of the CIDG to MACV control caused the conflict in Vietnam to lack a true dedicated counterinsurgency force until the institution of the CORDS program, which essentially re-started the CIDG program, but with national level authority and buy-in from conventional force commanders. ${ }^{1}$ With the answer to that preliminary question, a price tag so high, and implications so far-reaching, a clear picture of why the CIDG was moved in the first place was never adequately discussed by the memoirs of the persons involved or the document trail that enforced it. Why was the CIDG moved? What problem did this move solve, and did it solve it effectively? Was the decision based in military measures of effectiveness or other factors? The answers to these questions and the future implications for military and civilian decision makers are the subject matter of this monograph.

\section{$\underline{\text { Purpose of the Study }}$}

The purpose of this study is to demonstrate that a series of internal political actions at the national level met with a practical problem, and the resulting solutions' effect was the loss of the

\footnotetext{
${ }^{1}$ James H. Willbanks, Abandoning Vietnam: How America Left and South Vietnam Lost Its War (Lawrence, KS: University Press of Kansas, 2004), 56-8.
} 
only dedicated Pacification/Counterinsurgency program in South Vietnam until the CORDS program gained headway in 1969. National political issues effect practical applications of military power, but this single, simple, innocuous, and straightforward seeming decision would end up being one of the most influential decisions of the Vietnam War. The politics of this decision involved the struggles between the domestic and foreign policy of the Administration of President John F. Kennedy, the Kennedy Administration and the Department of Defense (DoD), the Kennedy Administration and the CIA, the internal politics of the $\mathrm{DoD}$, the internal struggles between the JCS and CIA leadership, as well as the simple biases of the people involved. These political interplays and the institutional inertia built up through their conduct all contributed to Secretary of Defense Robert S. McNamara's decision, which on the surface looked like a quick and easy fix to a straight-forward problem. Understanding how that single innocuous decision, with such enormous ramifications in hindsight, occurred, will enable future military and civilian generations to understand and effectively demonstrate the risk of simple yet potentially disastrous decisions to the national political and military authorities making them.

\section{$\underline{\text { Scope }}$}

The scope of the material presented in this study is limited to an examination of the impetus to change operational control of the CIDG and the cascade of events that led to this decision. Although a study of the effects of a single action upon the entirety of the Vietnam War, the focused time period of this study is limited to the conflicts early beginning. The limits of the time period discussed begin in the early 1950s with the Administration of President Dwight D. Eisenhower and end with the successful completion of Operation Switchback in July of 1963 under the Kennedy administration. The study excludes the conflict in Laos and the administration's reactions to it in the same time period. A narrow aperture into future events, from 1963 - 1969, is necessary to demonstrate the far-reaching nature of the decision to change 
operational control of the CIDG, however, the preponderance of information presented is pre1964.

This study is not an examination of the effects of the movement of the CIDG program. It is also not a commentary of the events examined. This study is intended to provide an understanding of the relationship between the Kennedy administration and the senior military leadership of the time, examine how national level military decisions were made within the Kennedy administration, and display the momentum that built leading toward the inevitability of the decision to change control of the CIDG program.

\section{Literature Review and Purpose of Study}

Research for this monograph was conducted using official macro histories for context and to understand what the CIDG program was. Memoirs, analyses of the histories, and declassified documents were used to understand the effects of the movement of the CIDG; an analysis of United States government internal policy, politics, and context was examined to determine why. The US Army official histories provided an understanding of the conflict as a whole and the CIDG program in particular from both the conventional force leadership and advisory mission perspectives. The memoirs and analyses of individuals involved with the military aspects of the conduct of the war provided a detailed analysis of the effects of the programs change of operational control from the CIA to the DOD. A detailed examination of the political context to the war through a combination of memoirs, documents and analyses of the foreign policy, internal government strife, and changes in policy that arose from these factors, was necessary to understand the many reasons that culminated in the decision to move the program. Finally, an analyses of the actions of individual actors within these events that led to these decisions was conducted through official documentation, published internal analyses of members of the 
administration and analyses of the psychological factors led to an understanding of the politics of the civilian and military leadership relationship narrative behind the decision.

The official US Army histories provided coverage of the era, including the global context for the conflict, and detail the strategic, operational, and tactical policy that was instituted throughout. These histories were written following the war as chronological compilations in the effort to capture the facts of the events and to help others understand what had actually happened, with a very simple and broad analysis. The Joint Chiefs of Staff and The War in Vietnam - 19601968 Part 1, 2, 3 (History of the Joint Chiefs of Staff) official history described the global context and strategic national policy decisions and the events that influenced those decisions through the presidential administrations, military leadership, ambassadors, and CIA representatives viewpoints. The MACV: The Joint Command in the Years of Escalation, 1962-1967, and MACV: The Joint Command in the Years of Withdrawal, 1968-1973, official histories, described policy decisions, placed events within the country, and detailed the implementation methodology of those policies from 1962 to the United States withdrawal in 1973. These texts detailed both the evolution and efficacy of the MACV and the Government of Vietnam (GVN) as well as the evolution and efficacy of the policies and programs of both that attempted to coordinate and support efforts to create the military and government of South Vietnam. In so doing, they portrayed the separate nature of the conflict, the GVN non-involvement in the security and governance of the rural populace, corruption, and meddling in military affairs for personal gain.

The operational and tactical implementation of policy was relayed in US Army Counterinsurgency and Contingency Operations Doctrine 1942-1976, Advice and Support the Early years, and the Final Years 1965-1973, which provided detailed descriptions of the operational and tactical level actions that occurred in the advisory group and the evolution from purely advisory efforts to active United States combat escalation. These sources provided a summary of policy and the "whys" of how events unfolded and the people involved. These texts 
displayed a general United States lack of preparedness for counterinsurgency (COIN) operations and the disjointed efforts taken by the Military Assistance Advisory Group (MAAG) and MACV, the CIA, and the State Department in failing to create a unified structure to conduct inter-related operations to achieve the strategic desired endstate through combined efforts.

The intermediary analytical readings following the detailed official histories served to define the disparate actors in the operation and delineate the problems between each: the conventional military counter-guerrilla emphasis, lack of a common operational framework displayed by the separation of pacification from combat operations, the operational crosspurposes in which the Special Forces and CIA attempted to operate, and the inability of the GVN to support either the military or pacification efforts. The focal point for analyzing potential connections between the actors became the CIDG program, which was used by all four actors, and had enough source material to conduct a detailed analysis of the effects of this single program upon each. The CIDG's role with each actor in the problem can be illustrated through its initiation as a pacification effort by the CIA, under direction of the US Ambassador, taken over by the MACV, changed to a counter-guerrilla strike force training mission under conventional military and South Vietnamese Special Forces leadership, with continual GVN disdain and lack of support. Vietnam Studies - US Army Special Forces 1961-1971, by Colonel Francis J. Kelly, provided a clear evolution of the CIDG program and the policy behind it from the perspective of a former $5^{\text {th }}$ SFG Group Commander in Vietnam. It was written 1972, immediately following the war, in the effort to portray the image of the Special Forces through its many accomplishments throughout. It was written at the beginning of the era in which the conventional Army leadership simply wanted to forget that Vietnam and Counterinsurgency had even existed as they focused upon doctrine to conventionally defeat the Soviet Union and the "volunteerization" of the draftee army. COL Kelly intended to portray SF in a positive light to fight the institutional momentum within the military against conducting limited wars and against the independent and 
unconventional "cowboy” counterinsurgency specialized forces that fight them. It is a clearly written, data based account of the contribution of SF to the conflict in Vietnam, relaying the CIDGs initiation as a CIA mission, through the handover in Operation Switchback, and the consequent usage as a mobile strike force.

Multiple analyses and documents describe the inefficacy of the usage of the CIDG as an offensive counter guerilla force and the mismatch of force to mission it entailed. The $5^{\text {th }} S F G$ Operational Report for Quarterly Period ending 31 July 1967, the $5^{\text {th }}$ SFG Outline History of Company D, 1962-70 by SPC/5 Franklin Jurco and the GVN CIDG Political Action Program 1965, describe the CIDG program as a successful method of winning back terrain and population from the insurgency until two factors changed it utterly, the change of mission in 1963 to offensive operations and the distrust of the GVN and ARVN. In the declassified Memorandum, Report on Forrestal Group Trip to SVN - 19 Nov - 7 Dec 1964, LTC Knight described in December of 1964 that the CIDG program had not lived up to expectations and has changed mission from that of recovering people and terrain to that of killing National Liberation Front (NLF), commonly referred to as the South Vietnamese Communists or Viet Cong (VC) guerilla forces, relegating the CIDG forces to low level mercenaries. ${ }^{2}$ He believed that Pacification was failing due to the disjointed nature of the effort at all levels and lack of care of both the United States and South Vietnamese governments. He also said that these shortcomings were well known. Further evidence of the lack of a clear pacification and military effort connection exists; however, these documents clearly imply the failure of interaction that occurred. LTC Knight's report was written less than one year after the completion of Operation Switchback to provide an analysis of the efficacy of all paramilitary operations to the Special Group for Counterinsurgency;

\footnotetext{
${ }^{2}$ Knight, H.H., “'Report on Forrestal Group Trip to SVN - 19 Nov - 7 Dec 1964,’” (Office of the Special Assistant for Counterinsurgency and Special Activities Programs \& Review Division), 1.
} 
there is no evidence or indication that his analysis was endorsed or supported by civilian or military leadership that could have made a difference.

Examination of the military aspects of the war, through memoirs and analyses of individuals involved, provided a detailed analysis of the effects of the program and its change of operational control. The conventional army used the tactics it understood to accomplish a strategy that was designed to use those tactics to best effect. The Army and Vietnam primarily covers the conventional military, while utilizing background context of the State Department and CIA. His contention was that in Vietnam counterinsurgency operations were actually counter-guerrilla because counterinsurgency was not organizationally well understood. Senior civilian and military leaders at all levels failed to adapt to the actual situation in favor of falling back upon the conventional doctrine they knew and understood. The hyper-conventional mindset of 1961 was exemplified by the central debate as to whether or not the United States should attack and seize Hanoi to stop the Communist-sponsored insurgency in South Vietnamese insurgency rather than an understanding that the population of South Vietnam was in revolt and required attention. Ambassador Galbraith assessed that the insurgency would be like the Sioux toppling the US Government, the insurgency in South Vietnam was only 15-18,000 lightly armed troops defeating the whole Army of the Republic of Vietnam (ARVN). He believed that should the ARVN be well deployed on behalf of an effective government, they would win. ${ }^{3}$ However, even CIA officials, such as Walt Rostow, a former OSS member, placed great emphasis on air power and massive retaliation as the main means of counterinsurgency. ${ }^{4}$ The Army had no counterinsurgency doctrine, as further demonstrated in the 1961-2 Army War College Curriculum, The US Army Role in Counterinsurgency, which clearly states, “an overall doctrinal basis for the conduct of

\footnotetext{
${ }^{3}$ Andrew F. Krepinevich, The Army and Vietnam (Baltimore, MD: Johns Hopkins University Press, 1988), 63.

${ }^{4}$ Ibid., 33-4.
} 
Army activities in counterinsurgency operations does not exist... when produced, it must be comprehensive to include offensive as well as defensive applications.” ${ }^{5}$ This doctrinal gap relegated the task of counterinsurgency to a special operation for the Special Forces, Psyops, and Civil Affairs community, under MACV Operational Control. The US Army and ARVN conducted counter-guerrilla operations under the direction of conventional MACV leadership until 1967.

The conclusion that the US military could not conduct counterinsurgency was further supported by the autonomy and divergence of purpose in which each disparate actor operated. Our Vietnam - the War 1954 - 1975, detailed the workings of each administration in detail from the national to military leadership. It includes clear indications of opposing viewpoints between the military and civilian leaders at home and within South Vietnam, conflicting priorities of effort, and implementation of policy based upon improper understanding of the operational and tactical environments. Just and Unjust Wars, related the conventional ROE and methodology employed as contrary to everything a counterinsurgency effort hopes to achieve, yet sanctioned by the strategic and operational level leadership as appropriate to achieving the objective of exhausting the enemies will to fight through destruction of combat personnel. Abandoning Vietnam, detailed the continued disparity between the mission actors even under the "One War" concept of Vietnamization and Pacification as the method to achieve success at the Paris Peace Accords. However, even under “One War” policy and the new focus upon population security, there was no change in tactical level actions, the US military and ARVN continued to conduct search and destroy missions under new names. The real changes that led to successful pacification efforts were unpredicted and uncoordinated events such as the destruction of the

\footnotetext{
${ }^{5}$ US Army War College, “The US Army Role in Counterinsurgency, US Army War College Curriculum” (Carlisle Barracks, Pennsylvania, 1961), 37.
} 
native insurgents during the Tet Offensive in 1968, the CIA CORDS program coming to fruition in this vacuum, and the GVN under President Nguyen Van Thieu finally taking an active interest in pacification efforts. Competing missions and roles without clear direction and inter-relation not only hampered unity of effort, but also had operations operating at cross-purposes.

Clear indicators of operations at cross-purpose were the special missions being conducted by the Special Forces and the CIA. In United States Special Forces and Counterinsurgency in Vietnam: military innovation and institutional failure, by Christopher Ives, written in 2006 in the effort to understand what was occurring in Iraq and Afghanistan, detailed the counterinsurgency effort of the Special Forces that were occurring but which were never capitalized upon, or integrated into, a larger country plan, but sabotaged by mission change and continued conventional emphasis on and usage of search and destroy missions. Further, Vietnam Declassified - the CIA and counterinsurgency, by Thomas L. Ahern, Jr., detailed CIA continuous pacification efforts in conjunction with the US Ambassadors, from the Strategic Hamlet program, the CIDG, Peoples Action Teams, through the CORDS program. These programs were always a series of independent experimental counterinsurgency actions that, as with Special Forces efforts, were hampered through conventional force counter guerilla strategic focus, but the GVN officials and ARVN leadership, seeing them as American projects best left to the Americans, continued to consolidate power for themselves within the GVN. Mr. Ahern also relates the frustration of the CIA in that neither the administration nor the CIA had intended for this change to occur, this decision was made at the MACV Headquarters in Saigon forcing the insurgency experts of the Special Forces to conduct operations contrary to the counterinsurgency-centric policy of the Kennedy administration. In 1970, before the US withdrawal from Vietnam, CORDS Director R.W. Komer, wrote The Impact of Pacification on Insurgency in South Vietnam. Komer described the pacification strategy of GEN Abrams “One War” and stated that until 1967, under what was deemed a "new model” in the CORDS program, which was actually simply a reflection 
of the initial CIDG program, there had been no unified pacification effort until CORDS. ${ }^{6}$ The civilian usage of the term pacification being synonymous with counterinsurgency concepts and theories. The three over-lapping aspects of the war, the military, government, and the need to suppress the Viet Cong in order to win the peasantry, though not at odds in intent, were continually at odds in practice.

Following the detailed examination of the military effects of the change in control of the CIDG, the real question became understanding why it had occurred. The political context of the war, examined through a combination of memoirs, documents and analyses of the foreign policy, internal government strife, and changes in policy that arose from these factors, was necessary to understand the many causes that culminated in the decision to move the program. However, there were no documents or memoirs that detailed the reason for the decision to move the CIDG beyond the practical command and control issues associated with its expansion. The explanations given by the persons involved proved entirely inadequate. R.W.Komer, in Bureaucracy at War: US Performance in the Vietnam Conflict, mentioned the move in two sentences: "When jurisdictional issues arose, as in the case of CIA use of US Special Forces personnel, these were usually resolved by a return to the traditional relationships. Reluctance to change the traditional relationship of civilian versus military leadership, even in a highly atypical conflict, was also a powerful institutional constraint." ${ }^{7}$ William Colby, in both of his books Lost victory: a firsthand account of America's sixteen-year involvement in Vietnam and Honorable men: my life in the CIA, underlined the Kennedy administration's policy of distrust toward the CIA and its inability to support the mission themselves while Secretary McNamara forced the decision upon him with

\footnotetext{
${ }^{6}$ R. W. Komer, "Impact of Pacification on Insurgency in South Vietnam" (Presentation at the Biltmore Hotel, Los Angeles, California, September 8, 1970), 1.

${ }^{7}$ R. W. Komer, Bureaucracy at War: U.S. Performance in the Vietnam Conflict, Westview special studies in national security and defense policy (Boulder, CO: Westview Press, 1986), 95.
} 
little recourse, but only as an aside on a single page. COL Kelly, in Vietnam Studies - US Army Special Forces 1961-1971, simply described Operation Switchback while describing the logistical methods employed between the CIA and MACV. Secretary McNamara's involvement is only described through the accounts of the July Honolulu Conference in the History of the JCS ${ }^{8}$ and the decision made there.

The effects of this decision were extremely far-reaching, but an examination of why it occurred was lacking. Further research led to the institution of NSAMs 55-57 in 1961, which changed responsibility for all paramilitary operations to DOD control. On Strategy, Dereliction of Duty, and Flawed By Design, each describe a flawed system that created strife between the NSC, JCS and Kennedy administration pre-dating the Vietnam War which led to the diminished capacity of the military leadership to provide civilian authority with military assessments for foreign policy decisions. The principal sources detailing the reaction to the Bay of Pigs and the Cuban Missile Crisis by the Kennedy administration within this system was described in the doctoral dissertation President John F. Kennedy and His Joint Chiefs of Staff, the summary Operation Zapata: the "ultrasensitive" report and testimony of the Board of Inquiry on the Bay of Pigs, and Groupthink: psychological studies of policy decisions and fiascoes.

${ }^{8}$ Graham A. Cosmas, The Joint Chiefs of Staff and The War in Vietnam - 1960-1968 Part 1 (History of the Joint Chiefs of Staff) (CreateSpace Independent Publishing Platform, 2013), 249. 


\section{THE CIVILIAN IRREGULAR DEFENSE GROUP AND OPERATION SWITCHBACK}

\section{$\underline{\text { Summary of the CIDG }}$}

In Vietnam the CIA was responsible for a wide range of operations including intelligence gathering, paramilitary, and rural pacification. Pacification, the civilian concept of counterinsurgency operations, was focused upon winning back the populace from the National Liberation Front communist insurgency against the US-sponsored government of South Vietnam. To conduct Pacification operations the CIA used an experimental amalgam of many programs that attempted to secure and strengthen popular support for the government in rural areas, specifically the economically vital Mekong Delta and rural Central Highlands areas. "The Central Highlands were important because they dominated the Mekong Delta to the south, the rice producing lands to the east, and provided the Viet Cong numerous trails and supply routes from North Vietnam, Laos, and Cambodia into South Vietnam's Delta region. Approximately 700,000 Montagnard $^{9}$ tribesmen lived in the Central Highlands and since Vietnam’s division in 1954 had been harassed and exploited as much by the VC as they had been ignored by the South Vietnamese government.” ${ }^{10}$ These programs met with varying degrees of success depending largely upon the nature of support offered and the involvement of the South Vietnamese government. The most successful of these programs was the Citizens Irregular Defense Group, (later changed to “Civilian”). “In the 13 months following December 1961, the CIDG political action program recovered and secured several hundred villages, some 300,000 civilians and

\footnotetext{
${ }^{9}$ The term "Montagnard" is French, simply meaning "mountain people.” The Montagnards are the aboriginal people (ethnically from Mon-Khmer, Tai, or Malayo-Polynesian groups) who, centuries earlier, had been driven into the mountain highlands by the Vietnamese. The lowlands ethnic Vietnamese used the pejorative term "moi," meaning "savage" and treated them with contempt. US Special Forces simply called them "Yards," a term of endearment." Robert W. Jones Jr. "A Team Effort: Special Forces in Vietnam June-December 1964," Vertias, Volume 3, Number 1, 2007, 24-36. They are a varied group that identify themselves by various names. The term "Montagnard" is an outsider term that has fallen into disfavor with these groups. no. 4 (2009).

${ }^{10}$ Eugene G. Piasecki, “Civilian Irregular Defense Group: The First Years: 1961-1967,” Veritas 5,
} 
several hundred square miles of territory from the Viet Cong, utilizing some 38,000 armed civilian irregulars. These people who fought well on their home ground and without support from conventional [South] Vietnamese armed forces, had almost unbroken success against the Viet Cong." 11 The CIDG's success became the template for future operations and required exponential expansion. Unfortunately, this was not a level that the CIA was capable of effectively commanding, administrating, or logistically supporting, so Secretary McNamara decided to remove operational control of the CIDG from the CIA and place the program within the DoD. ${ }^{12}$ The change was named Operation Switchback.

The changes under Operation Switchback included the creation of a Special Forces Group Headquarters answerable to the MACV commander, the assignment of Special Forces Operational Detachment Alpha's (SFODA) to the conventional force Corps Advisors, and change of mission from counterinsurgency (Pacification) to offensive operations. The $5^{\text {th }}$ Special Forces Group Headquarters was created within the MACV. The $5^{\text {th }}$ SFG HQ provided battalion and company level logistical and administrative support to the SFODA's that were conducting the CIDG mission. The change in headquarters was an upgrade from the Provisional Special Forces Headquarters that was no longer adequate for an operation of the size and scope of the expanding CIDG. These SFODA's were under the direct command of the Corps adviser, supported by the $5^{\text {th }}$ Special Forces Group HQ. The MACV “...changed the primary mission of the Green Berets and the irregulars they advised, from area pacification to the provision of strike forces to patrol and interdict Viet Cong infiltration routes across the border. It thereby largely diverted the CIDG program from its original focus on paramilitary counterinsurgency to more conventional

\footnotetext{
${ }^{11}$ US Army, “The GVN CIDG Political Action Program 1965” (History of the Vietnam War on Microfilm, March 3, 1965), 1.

${ }^{12}$ Cosmas, The Joint Chiefs of Staff and The War in Vietnam - 1960-1968 Part 1 (History of the Joint Chiefs of Staff), 249-50.
} 
reconnaissance and combat.” The CIDG became a light infantry strike force of counter-guerrilla specialists conducting border and route reconnaissance, responding as quick reaction forces for base defense, and hit-and-run raiders against infiltrating North Vietnamese Army (NVA) regular troops and the logistical trains of the Ho Chi Minh Trail supporting the NLF insurgency throughout Southern Vietnam. This mission change and the turmoil that followed the assassination of South Vietnamese President Ngo Dinh Diem on November 1, 1963, changed the nature of Pacification efforts countrywide until 1969 under President Thieu’s Pacification program combined with the efforts of the Civil Operations and Revolutionary Development Support program. CORDS, with the national backing of the South Vietnamese government and the United States Government within the MACV structure, was essentially a replication of the earlier CIDG program, but with a better understanding of the counterinsurgency effort and necessity for national level support and representation at the MACV command table.

\section{Operation Switchback}

Operation Switchback, November 1, 1962 - July 1, 1963 placed the CIDG and the Special Forces advisers assigned to the program under the Operational Control (OPCON) of the conventional force command of the newly created Military Assistance Command, Vietnam (MACV) from the CIA's Combined Studies Division (CSD). ${ }^{13}$ The decision to move the CIDG program from the control of the CIA's US Mission in Saigon CSD to the DoD's MACV was due to the political changes implemented by President Kennedy and Secretary of Defense McNamara within the National Security Council (NSC) and the Joint Chiefs of Staff (JCS), the changes that resulted from the Bay of Pigs failure and successful Cuban Missile Crisis resolution, and the institutional inertia these created combined with practical implementation issues naturally

\footnotetext{
${ }^{13}$ Francis J. Kelly, Verne L. Bowers, and U. S. Department of the Army, U.S. Army Special Forces 1961-1971 (MilitaryBookshop.co.uk, 2011), 35, 37.
} 
produced by the success and exponential growth of the CIA's Pacification programs. The political factors for the movement of the CIDG included President Kennedy and Secretary McNamara’s distrust of the militaristic Eisenhower bureaucratic establishment, the dismantling of key apparatus of the NSC and JCS's influence over the president, and the fostering of an environment of distrust of the CIA and JCS following the Bay of Pigs and Cuban Missile Crisis. The changes resulting from the Bay of Pigs failure were documented by the Cuba Study Group(CSG), a group including Attorney General Robert Kennedy and GEN Maxwell Taylor. The CSG was created to analyze the failure to prevent future occurrences. The CSG's findings and recommendations are responsible for the movement of all paramilitary operations from the CIA to DoD control as evidenced in the conclusion drawn by the CSG, the recommendations made by the CSG, and the National Security Action Memorandums (NSAMs) published to introduce these recommendations as policy. The Cuban Missile Crisis resulted in widening the gap between President Kennedy and his administration from the military leadership of the JCS by reinforcing the perception that the crisis had been resolved by ignoring the JCS best military advice, not by following it. The practical factors for the move were based in the lengthy timeline proposed to make the Strategic Hamlet program effective. The timespan for effectiveness of the program was a problem due to the Kennedy administration's policy change from escalation to withdrawal, the program already falling behind schedule, and the expected exponential growth exceeding CIA support capabilities. ${ }^{14}$ The CIDG was placed under DoD operational control due to a cascade of events that began the day President Kennedy took office. The mounting institutional inertia, as described by Robert Komer ${ }^{15}$, swept into all facets of the White House and created the impression that not only could these New Frontiersmen accomplish anything, but that not even

\footnotetext{
${ }^{14}$ Cosmas, The Joint Chiefs of Staff and The War in Vietnam - 1960-1968 Part 1 (History of the Joint Chiefs of Staff), 250.

${ }^{15}$ Komer, Bureaucracy at War, 70.
} 
the most senior and experienced leaders were able to resist the pressure. President Kennedy's distrust of the military and CIA created an environment in which the Bay of Pigs incident was able to occur. Following the Bay of Pigs, his administration instituted the changes that empowered the secretary of defense, through the NSC and JCS, with oversight of all future paramilitary programs. The Cuban Missile Crisis provided the administration the confidence in itself to move forward inexorably having literally saved the world from nuclear destruction without the help of anyone but themselves. And, when the success of the paramilitary effort became too great for the CIA to handle alone, following these changes, it was decided to remove it from CIA control all together. This decision utterly changed the landscape in the war for South Vietnam by removing the only dedicated counterinsurgency force from the counterinsurgency mission until the implementation of the CORDS program. ${ }^{16}$

${ }^{16}$ Thomas L. Ahern, Vietnam Declassified: The CIA and Counterinsurgency (Lexington, KY: University Press of Kentucky, 2010), 221. 


\section{EFFECTS OF THE MOVEMENT OF THE CIVILIAN IRREGULAR DEFENSE GROUP}

Operation Switchback was the 1962-3 change of operational control of the Civilian Irregular Defense Group (CIDG) from the CIA's Combined Studies Division (CSD) to the Military Assistance Command, Vietnam. The lasting consequence of the decision to place the CIDG beneath the control of the MACV was the loss of a dedicated counter-insurgency force in the country of South Vietnam until the institution of the CORDS program. The conventional military was conducting COIN as a conventional war of exhaustion, under MACV the Special Forces were re-tasked from COIN to counter-guerrilla operations, and the loss of the CIDG severed the CIA's ability to conduct effective COIN. The conduct of the war used a conventional answer to an unconventional problem ${ }^{17}$ as evidenced by the conventional South Vietnamese military construction focus of the MAAG and MACV based upon the US Army experience in Korea, the MACV's misapplication and usage of COIN doctrine, and the tactical action vs. strategic mismatch that resulted from this application. ${ }^{18}$ The Special Forces mission was changed from conducting UW and COIN to offensive counter-guerrilla operations. The CIDG program lost the autonomy to experiment with the mission change to the exclusive conduct of offensive operations including border security, mountain operations and the MKE force. The conduct of these missions resulted in the misuse of the indigenous forces that made up the CIDG; the CIDG were no longer home guardsmen, but an offensive tool for which many had not originally signed

\footnotetext{
${ }^{17}$ Graham A. Cosmas and Center of Military History, MACV: The Joint Command in the Years of Escalation, 1962-1967 (Military Bookshop, 2011), 29.

${ }^{18}$ The conventional threat from the North Vietnamese was very real, and based upon the US Army's recent experience in Korea, it was at that time determined to be the greater of the military threats. However, the MACV conventional counterguerilla emphasis and the inability of the South Vietnamese to defeat the insurgency created the conditions in which they were unable to adequately train, equip, and organize a conventional force capable of defeating the conventional threat from the North Vietnamese independent of the military assistance of the United States.
} 
up. ${ }^{19}$ The CIA was unable to conduct effective Pacification or COIN until the institution of the CORDS program in 1967, creating a five-year gap in COIN operations capability for the entire country, as evidenced by the lack of a unified country-wide Pacification ${ }^{20}$ effort until the creation of the CORDS program, the CIA institution of the RF/PF as a popular indigenous force analogous to the original CIDG mission, and CORDS as the first Pacification program that received buy-in from the host nation. South Vietnam suffered under the misapplication of COIN doctrine until the CORDS program became effective. This inefficacy was due to the decision to remove the only unit specifically trained in COIN, and to that point the single most effective means of conducting counterinsurgency operations in the conflict, from the CIA and place them beneath the control of conventional force Corps Advisors and conventional commanders in the MACV. The conventional force commanders did not appreciate or understand the Special Forces or the counterinsurgency mission being conducted. The US Army War College curriculum of 1962, The US Army Role in Counterinsurgency, admitted that the US Army did not in fact even have COIN doctrine. ${ }^{21}$ The Corps advisors saw the Special Forces as irrelevant and considered the conventional advisors as capable as their Special Forces counterparts, SF simply bringing more unconventional methods of re-supply to the table. ${ }^{22}$ As such, the Corps commanders and MACV leadership relegated to near insignificance through misapplication of potential the CIDG forces and their Special Forces advisers for the remainder of the war.

${ }^{19}$ Christopher K. Ives, US Special Forces in Counterinsurgency in Vietnam: Military Innovation and Institutional Failure, 1961-63 (London: Routledge, 2012), 98-101.

${ }^{20}$ Pacification and Counterinsurgency were used regularly and interchangeably for the same type of operation depending upon the audience - civilians tended to use Pacification and military tended to use Counterinsurgency to describe the same mission.

${ }^{21}$ US Army War College, "The US Army Role in Counterinsurgency, US Army War College Curriculum," 41, 56.

${ }^{22}$ Army Concept Team in Vietnam, “Employment of a Special Forces Group”, April 20, 1966, 1, $58-61$. 


\section{CIVIL/MILITARY LEADERSHIP RELATIONS LEAD TO CHANGE}

\section{The Kennedy Administration: Policy-Making Is Politics}

Understanding comes in looking at the vital stuff of events themselves, in the interaction of the President, the Congress, the press, and special interests and in rivalries of the great Executive departments, State, Defense, and the Central Intelligence Agency, as they clash in the actual making of policy, in the crucible of events - in the struggle over organizational mandates, in the crisis of Soviet nuclear missiles in Cuba, of the Congo, Laos, and the guerrilla struggle in Vietnam.

- Roger Hilsman, To Move a Nation: The Politics of Foreign Policy in the Administration of John F. Kennedy

The decision to remove the CIDG from CIA control is rooted in the political dynamics of the relationship between the Kennedy administration and the existing military and intelligence bureaucracies. President Kennedy’s “New Frontiersmen” distrusted the Eisenhower era “Old Guard” bureaucracy and determined to change the system by placing the military firmly under the influence of the civilian authority. This political change is demonstrated by the empowerment of the secretary of defense for reform of the Department of Defense, the dismantling of key National Security Council and Joint Chiefs of Staff committees and apparatus, and the president's usage of a small group of civilian and chosen military advisers for national level military decision-making. In 1962 when the decision was made to move the CIDG, the prevailing attitude was that Secretary McNamara was firmly in control of the military and would ensure that projects affecting the war in Vietnam should be firmly within his exclusive purview.

President Kennedy’s administration was designed to be the antithesis of the Old Guard Republicans. The New Frontiersmen were a group of men that were part of President Kennedy's idea for the future, which would purposefully be the opposite of the past. "The New Frontier is here whether we seek it or not. Beyond that frontier are uncharted areas of science and space, unsolved problems of peace and war, unconquered problems of ignorance and prejudice, unanswered questions of poverty and surplus. It would be easier to shrink from that new frontier, 
to look to the safe mediocrity of the past, to be lulled by good intentions and high rhetoric..."23 The typical New Frontiersman was defined as the opposite of these things and was typically a man much like the president himself. They were men in their mid-forties, highly idealistic, articulate, and the polar opposite of the "Old Guard" mentality, which had controlled the Republican Party during the Eisenhower administration. President Eisenhower had been politically opposed to the Old Guard, which was against social reform and for nuclear deterrence with large-scale military-industrial complex supported conventional warfare. ${ }^{24}$ Although against the emergence of the military-industrial complex, President Eisenhower's administrations' "main elements of national security policy were fairly clear. They included placing main reliance on nuclear weapons to deter or defeat aggression of all varieties and avoiding involvement in limited wars...if the Armed Forces were prepared to cope with nuclear war, they could take care of all lesser contingencies.” ${ }^{25}$ President Kennedy instituted the opposite policy of flexible response to maintain the ability to conduct operations short of nuclear war, as he clearly articulated through his special recognition and support for the Unconventional Warriors of the US Army Special Forces in his authorization of the Green Beret for wear on October 12, 1961. President Kennedy used the New Frontier analogy to define himself and his presidency. They would not be lulled by the "Old Guard” within the military, President Kennedy would change the apparatus to serve him, not itself.

The entrenched bureaucracy of the JCS had been created to check the wartime power of a sitting president as evidenced by its mandate to check the future personal military decisionmaking authority exemplified by President Franklin D. Roosevelt during WWII and the NSC and

\footnotetext{
${ }^{23}$ John F. Kennedy, "Democratic National Convention Nomination Acceptance Address 'The New Frontier”" (Memorial Coliseum, Los Angeles, CA, July 15, 1960).

${ }^{24}$ Maxwell D. Taylor, Swords and Plowshares, 1st ed. (New York, NY: W. W. Norton, 1972), 164.

${ }^{25}$ Ibid.
} 
JCS extreme entrenchment in bureaucratic process. ${ }^{26}$ The NSC and JCS structures were found to be cumbersome and contrary to the informal collegial leadership style preferred by President Kennedy. President Kennedy preferred working groups and specialized task forces to analyze problems, believing the NSC had become a self-serving apparatus with the goal of perpetuating inter-service rivalry rather than providing the president honest advice. ${ }^{27}$ He believed in creating groups with "high cohesiveness and of an accompanying concurrence-seeking tendency that interfered with critical thinking...”28 The National Security Act of 1947 created the Department of Defense to unify the Army, Navy, and Air Force into a single structure. The Act also created the NSC for the executive branch to coordinate national security policy and "advise the president on domestic, foreign, and military policies, and to ensure cooperation between the various military and intelligence agencies.”29 President Kennedy believed he faced a classic Principal-Agent organization theory problem. "Presidents (principals) have no choice but to rely on bureaucrats (agents) who do not completely share their interests; this necessity, coupled with the president's inability to monitor agency activity fully, provides fertile ground for bureaucratic noncompliance. ${ }^{30}$ However, in realizing his ambition to be free of these apparatus and creating a small group of trusted and vested decision-makers, he would also be setting the stage for his future decisions to be made with a distinctive lack of group diversity and interdependence with outside entities. The burden of widespread diversity and interdependence, although indeed

\footnotetext{
${ }^{26}$ Gordon Nathaniel Lederman, Reorganizing the Joint Chiefs of Staff: The Goldwater-Nichols Act of 1986, Contributions in military studies no. 182 (Westport, CT: Greenwood Press, 1999), 7-23.

${ }^{27}$ Steven L. Rearden, Council of War: A History of the Joint Chiefs of Staff, 1942 - 1991 (Washington, DC: NDU Press for the Joint History Office, Office of the Director, Joint Staff, Joint Chiefs of Staff, 2012), 211-213.

${ }^{28}$ Irving L. Janis, Groupthink: Psychological Studies of Policy Decisions and Fiascoes, 2nd ed. (Boston, MA: Houghton Mifflin, 1982), 9.

${ }^{29}$ Stephen A. Cambone, A New Structure for National Security Policy Planning, Significant issues series 20, no. 3 (Washington, DC: CSIS Press, 1998), 228-32.

${ }^{30}$ Amy B. Zegart, Flawed by Design: The Evolution of the CIA, JCS, and NSC (Stanford, CA: Stanford University Press, 1999), 47.
} 
making decision-making laborious and time consuming, serves to effectively increase the viability and breadth of options available to him as a leader, potentially leading to greater chances of success. ${ }^{31}$ His lack of these two elements would reduce his power to achieve his desired outcome, and set the stage for groupthink to set in during critical decisions made at the beginning of his Presidency.

In order for President Kennedy to remove the entrenched “Old Guard” infrastructure of the military establishment he would need a civilian from the outside, who could critically assess and change the system without having been a product of it. President Kennedy regarded intellect, academic credentials, and compatibility with his informal style of leadership and decision making as critical traits in the members chosen for the inner circle of his cabinet. Robert Strange McNamara was on a short list of potential selectees for this position due to his WWII military experience, exemplary academic credentials as the youngest Harvard Business School associate professor ever, and executive-level experience as the first president of the Ford Motor Company who did not come from the Ford family. Mr. McNamara had broken the family reign of leadership through the selection of a team ideally suited to the task combined with sheer analytical talent and hard work. He would use this blueprint to change the military establishment from within the Department of Defense. Secretary McNamara chose and assembled a team, as was one of his two requests of the president prior to accepting appointment to the office, to have personal control over all appointments within his Department, ${ }^{32}$ and began analyzing the Department for efficiency, using his WWII experience as a United States Army Air Forces officer in the Office of Statistical Control and included responsibility for the analysis of U.S. bombers' efficiency and effectiveness, especially the B-29 forces commanded by Major General Curtis

\footnotetext{
31 John P. Kotter, Power and Influence (New York, NY: Free Press, 1985), 36.

${ }^{32}$ H.R. McMaster, Dereliction of Duty (New York, NY: HarperPerennial, 1997), 3.
} 
LeMay in India, China, and the Mariana Islands. ${ }^{33}$ He selected a group of highly intellectually talented individuals dubbed "Whiz Kids" to analyze the DoD as they had the Ford Motor Company. His goal was to assist the presidents’ vision of a modern defense strategy of flexible response by using outside techniques including “economic analysis, operations research, game theory, computing, as well as implementing modern management systems to coordinate the huge dimension of operations of the DoD.”34 The analyses showed layers of bureaucracy would have to be dismantled, the first being the National Security Council (NSC).

"President Kennedy prefers to invite [to White House meetings] only those whose official views he requires or whose unofficial judgment he values...”35 President Kennedy’s Administration eliminated the Planning Board Committee and the Operations Coordinating Board (OCB). The removal of these two committees significantly reduced the ability of the Joint Chiefs of Staff (JCS) to influence policy decisions. The JCS lost access to the president and were unable to influence the NSC agenda or voice opinions directly to the president negating the JCS's ability to provide unfiltered military feedback in both policy and operational matters. ${ }^{36}$ President Kennedy removed the JCS ability to frame the agenda toward discussion they felt necessary and valuable. "By making it easier for some people to have access than others, by providing for the accumulation of one kind of information and not another, or by following procedures that let some problems rise to the top of the government's agenda before others-in all these ways some organizational arrangements facilitate certain kinds of policy and other organizational arrangements facilitate other kinds of policy." ${ }^{37}$ This example of agenda-framing removed the

${ }^{33}$ Richard B. Frank, Downfall: The End of the Imperial Japanese Empire (New York, NY: Penguin, 2001).

${ }^{34}$ Del Webb, “The Pentagon's Whiz Kids,” Time Magazine LXXX No. 05 (August 3, 1962).

${ }^{35}$ Theodore C. Sorensen, Decision-Making in the White House: The Olive Branch or the Arrows, Columbia classics (New York, NY: Columbia University Press, 2005), 63.

${ }^{36}$ McMaster, Dereliction of Duty, 5.

${ }^{37}$ Roger Hilsman, To Move a Nation: The Politics of Foreign Policy in the Administration of John 
ability of the JCS to frame the military discussion as they believed necessary to provide the president the best possible military advice; they were relegated to "as Sherlock Holmes might put it, dogs that fail to bark.”38 The changes were meant to increase efficiency and speed of action through exclusion of members whose input was deemed tediously unnecessary and overwhelmingly slow moving.

However, the unforeseen problem that developed was the loss of checks and balances from senior military leadership in both military and foreign affairs decisions that the system had originally been designed to create following WWII. "Under Kennedy, the NSC became a shadow of its former self. Cutting staff by one-third, he abandoned the practice of developing broad, longrange policies in the NSC and used it primarily for addressing current problems and crisis management." ${ }^{39}$ The loss of these apparatus, combined with the president’s proclivity for specialized small groups of trusted advisors, who inherently believed themselves at odds with high-level military leadership, for decision-making led to the administrations fall into groupthink. ${ }^{40}$ They created the conditions for “.... mode of thinking that people engage in when they are deeply involved in a cohesive in-group, when members' striving for unanimity override their motivation to realistically appraise alternative courses of action.” ${ }^{41}$ The failure of these apparatus, following these changes, to provide the president and his small group of advisers sound military advice prior to a final decision on a course of action manifested itself greatly in the Bay of Pigs failure and the administration's perceptions of the military leadership following the Cuban Missile Crisis.

\footnotetext{
F. Kennedy (New York, NY: Dell Publishing Co., 1964), 17.

${ }^{38}$ Joseph S. Nye, The Future of Power (New York, NY: PublicAffairs, 2011), 12.

${ }^{39}$ Rearden, Council of War, 212.

40 "Groupthink refers to a deterioration of mental efficiency, reality testing, and moral judgement that results from in-group pressures.” Janis, Groupthink, 9.

${ }^{41}$ Ibid.
} 


\section{The Cuba Study Group}

The Bay of Pigs failure resulted in the formation of the Cuba Study Group, whose findings are directly related to the movement of the CIDG and all other paramilitary operations from CSD (Combined Studies Group, CIA in Vietnam) to the MACV as evidenced in the conclusion of the CSG, the six recommendations made by the CSG, and the NSAMs (National Security Action Memorandum) that were published to accomplish these recommendations.

In the atmosphere of this distrust, President Kennedy tasked General Maxwell D. Taylor to head a commission to study the Bay of Pigs failure for future lessons. The Bay of Pigs failure resulted in the formation of the Cuba Study Group (CSG) whose findings are directly related to the movement of the CIDG and all other paramilitary operations from CSD (Combined Studies Group, CIA in Vietnam) to the MACV conventional military leadership as evidenced in the CSG's Memorandums that outlined the results of their investigation. These memorandums included: Memorandum 3, the Conclusions of the CSG, Memorandum 4, outlined the 6 recommendations made by the CSG, and the National Security Administration Memorandums (NSAMs) 55-57 that were published to accomplish these recommendations. The key points of Memorandum 3, Conclusions of the Cuba Study Group, were that there had never actually been a way for the operation to remain plausibly deniable for the United States, the operation should not have been run by the White House in Washington, and the JCS failed to strongly relay their negative assessment of its chances of success from the beginning. Memorandum 4, Recommendations of the Study Group, gave 6 recommendations, including detailing the creation of "a Mechanism for the Planning and Coordination of Cold War Strategy," "Responsibility for" and "Improvement of Effectiveness in the Paramilitary Field," and "Relations of the JCS to the 
President in Cold War Operations." ${ }^{42}$ From these recommendations a series of NSAMs were published to enact these recommendations: NSAM 55 placed the Joint Chiefs in control of paramilitary operations, NSAM 56 directed the JCS to fully re-assess its paramilitary capabilities, and NSAM 57 assigned the Special Group, 5412 Committee to perform the functions of the Strategic Resources Group detailed in Memo 4 Recommendations. The Cuba Study Group was formed in the aftermath of the Bay of Pigs failure to determine future policy for all paramilitary operations and greatly impacted the conduct of counterinsurgency operations in Vietnam by placing authority for all paramilitary operations firmly beneath the conventional force leadership of the MACV.

The key points of Memorandum 3, Conclusions of the Cuba Study Group, were that deniability could not have been feasibly maintained, there was not an appropriate apparatus in place to control the operation on the ground and that the JCS had failed to adequately advise the president as to their actual opinion of Operation Zapata. The first finding was that secrecy had been essential to the success of Operation Zapata; however, not only had secrecy been lost, but there in reality had been no feasible way to conduct an operation of its size and scope while retaining plausible deniability. The nation's premier intelligence agency had failed to maintain the secrecy of this operation. The training camps in both Guatemala and Nicaragua were so grossly overt that the Soviet news agency Tass announced the buildup of men and troops in Guatemala for the express purpose of the invasion of Cuba. Student groups and Cuban spies were able to pinpoint the locations of these bases, prompting the President of Guatemala to publicly denounce these allegations. ${ }^{43}$ Additionally, the pre-emptive air strikes against the Cuban air force

\footnotetext{
${ }^{42}$ Luis Aguilar, Operation Zapata: The "Ultrasensitive” Report and Testimony of the Board of Inquiry on the Bay of Pigs. (Frederick, MD: Aletheia Books, 1981), 44-53.

${ }^{43}$ Howard Jones, The Bay of Pigs, Pivotal moments in American history (Oxford, NY: Oxford University Press, 2008), 34.
} 
and the use of US equipment and transport from the airfields and ports in Nicaragua and Guatemala were both impossible to hide from foreign intelligence services and so blatantly US operations that they could not have been denied following the infiltration of an invasion force onto the Cuban mainland. Finally, the JCS considered these United States interventions on behalf of the invading liberation force to be critical to the success of the mission. The JCS assessed that the US Air Force would be needed to provide air cover for any landing force; however, their opinion was not properly solicited and the air strikes they planned in support of the beach landing were cancelled due to the administration's continued demand for deniability, which had never actually existed. ${ }^{44}$ These conclusions begged to question the CIA's ability to independently and clandestinely conduct operations of this magnitude, which led to the agency's future loss of autonomy, directly impacting the future operational control of CIA projects in Vietnam.

The CSG concluded that the Bay of Pigs operation should not have been run from The White House in Washington, DC. The reasons stated were the distance from the conflict occurring in the field and the disconnect between the political objectives and the military execution of the operation which dismissed any reasonable expectation of mission success. Field command decisions were being made in Washington at a range that limited the appreciation of the situation on the ground by the decision makers, particularly in the case of ammunition and supply shortages, which may have initiated contingency operations had these shortfalls been known. ${ }^{45}$ Also, the Washington decision makers were concerned with the political and strategic goals of the operation, as well as attempting to implement the tactical execution, which caused tactical necessity to become subjugated to strategic objectives, leading to the failure of the entire operation. The clear lack of operational and tactical understanding and control embodied in this

\footnotetext{
${ }^{44}$ Jeffrey G. Barlow, "President John F. Kennedy and His Joint Chiefs of Staff” (University of South Carolina, 1981), 196.

${ }^{45}$ Aguilar, Operation Zapata, 42.
} 
conclusion would prescribe, most especially to the members of the Kennedy administration involved, including Secretary McNamara, a need for a clear military line of operational control for paramilitary operations within Vietnam. At the time Secretary McNamara decided to conduct Operation Switchback the CIA had been responsible for countrywide paramilitary, rural pacification, and intelligence gathering operations. ${ }^{46}$ For Secretary McNamara, in the aftermath of the Bay of Pigs, it would be clear that operational control should reside within an organization capable of handling the enormity of these operations, while supporting the strategic objectives of the president, and residing under his department's supervision.

The final conclusion was that the JCS failed to strongly relay their negative assessment of Operation Zapata's chances of success; the acquiescence of the JCS to the plan equaled tacit approval. ${ }^{47}$ The JCS was consulted on an ad-hoc basis to provide input about parts of the plan, but not the whole. The JCS was consulted, but not able to disseminate the plan in order to gain detailed analyses from subordinate experts. The entirety of the plan was kept secret from everyone involved except the CIA and President Kennedy’s inner-circle of decision makers. The JCS failed to strongly discourage the CIA and the president from the disastrous course of action that they had independently planned and selected; this was a function of the president and CIA only asking for the JCS military assessment after the decision to conduct the mission had been made. The JCS had no idea that the president was still undecided about the operation, but were told to provide an analysis based upon a series of political and tactical assumptions in a vacuum. Operation Zapata, according to some members of the JCS, had a 50 percent chance of success, provided all planning assumptions were valid. ${ }^{48}$ Political considerations had been allowed to take precedence over military necessity and caused the loss of deniability, the mismatch of political

\footnotetext{
${ }^{46}$ Ahern, Vietnam Declassified.

${ }^{47}$ Aguilar, Operation Zapata, 42.

${ }^{48}$ Barlow, "President John F. Kennedy and His Joint Chiefs of Staff,” 175-200.
} 
and tactical authority in the same body, and a lack of clear communication between the president and his senior military advisors. Political and strategic implications could not be ignored in future paramilitary operations, but the administration could not afford to operate in a similar vacuum in the future, an operational control mechanism would be needed and addressed through the CSG's recommendations.

The CSG's conclusions were valid and had to be addressed and corrected. ${ }^{49}$ The result of these conclusions was a series of recommendations, compiled in Memorandum 4, designed to create a government mechanism that could bring "into play, in addition to military and covert techniques, all other forces, political, economic, ideological, and intelligence, which can contribute to its success." ${ }^{50}$ The first Recommendation was to create a structure for this planning and execution, designate responsibility for paramilitary operations and re-define the relationship between the JCS and the president.

The primary problem had been the inability to "coordinate, foster and focus all available and necessary assets on the achievement of objectives approved by the President." 51 These assets and expertise were spread across the disparate governmental departments, disabling the administration's ability to effectively plan and coordinate across departmental lines while allowing each department to maintain responsibility for tasks assigned to cross-departmental operations. The solution, following the dissolution of the agenda-framing apparatus of the NSC and JCS that had been vital to the process of creating understanding for the president, ${ }^{52}$ had been to have weekly meetings by adhoc task forces organized for particular situations, which had been demonstrated to be unwise following the Bay of Pigs. The solution was to create a new

\footnotetext{
${ }^{49}$ The validity and applicability in the time/space of these conclusions is not being discussed or analyzed. The conclusions are pertinent due to the policy that was later implemented that directly affected the operational control change of the CIDG.

${ }^{50}$ Aguilar, Operation Zapata, 43.

${ }^{51}$ Ibid., 44.

${ }^{52}$ McMaster, Dereliction of Duty, Ch.1.
} 
permanent committee staffed by representatives of under-secretarial rank from State, Defense, and CIA under a full-time chairman reporting directly to the president. ${ }^{53}$ The committee was tentatively called the Strategic Resources Group (SRG). The SRG would employ a Cold War Indications Center (CWIC), to replace the current 5412 Committee that had been responsible for the Bay of Pigs, to specifically plan and develop Cold War missions in accordance with the presidents priorities. The SRG would assemble and review the entirety of the plan, submit the entirety to the president, and to the NSC, ensuring all opinions and assessments were clearly articulated between departments.

The second problem was to determine the department that retained responsibility for paramilitary operations. The definition of paramilitary operations in the time period being examined "is considered to be one which by its tactics and its requirements in military-type personnel, equipment and training approximates a conventional military operation.” ${ }^{54}$ Following the recommendation for the SRG, it was determined that to maximize flexibility and effectiveness of paramilitary operations, the SRG was to be in the loop on all paramilitary operations from the concept stage onward. The SRG would serve to increase interdepartmental coordination and utilization of resources to increase overall paramilitary operations effectiveness. Upon approval by the president for action, the SRG would assign primary responsibility for planning, interdepartment coordination, execution of the Task Force, and the department or individual best qualified to conduct and support the operation. Under this paradigm, the Department of Defense would likely have operational control over all overt paramilitary operations, with the CIA retaining operations wholly covert or disavowable. The CIA would retain control only if the paramilitary operation was "within the capabilities of the agency...Any large paramilitary

\footnotetext{
${ }^{53}$ Aguilar, Operation Zapata, 44-5.

${ }^{54}$ Ibid., 48.
} 
operation wholly or partly covert which requires significant numbers of military trained personnel, amounts of military equipment which exceed normal CIA-controlled stocks, and/or military experience of a kind and level peculiar to the armed services is properly the primary responsibility of the Department of Defense with the CIA in a supporting role.”55

With the SRG firmly in control of paramilitary operations, and the extreme likelihood of those operations being delegated to the Department of Defense, it was then necessary to define the role of the JCS in this construct in Recommendation 4. The intent of this recommendation was to delegate responsibility not only for the conventional operations of wartime defense of the country, but also the contributions to the Cold War that fell short of conventional war, in line with President Kennedy's policy of flexible response. The president placed primary responsibility for these operations with the JCS as his principal military advisors. The president assigned them the responsibility of ensuring that they initiate, and respond to, requests for military advice for all military operations, without reservation or hesitation. The Cold War and conventional war were interestingly clearly divided as two separate arenas of war, with the JCS responsible for having knowledge and expertise for the conduct of both. ${ }^{56}$

The Bay of Pigs failure had been due to the president and his administration's penchant for using ad hoc, informal meetings with specialists for major decision-making. ${ }^{57}$ "The failure of Kennedy's inner circle to detect any of the false assumptions behind the Bay of Pigs invasion plan can be at least partially accounted for by the group’s tendency to seek concurrence at the expense of seeking information, critical appraisal, and debate.”58 The JCS had felt no compunction to provide more adequate feedback than they had been asked for in

\footnotetext{
${ }^{55}$ Aguilar, Operation Zapata, 48.

${ }^{56}$ Ibid., 50.

${ }^{57}$ Barlow, "President John F. Kennedy and His Joint Chiefs of Staff,” Ch.1.

58 Janis, Groupthink, 47.
} 
compartmentalized and assumption-based format. The series of Cuba Studies Group recommendations were intended to ensure this would not happen in the future. Recommendation 2 especially, the recommendation for the placement of all paramilitary operations within the DoD, would have dire implications for the future of the entirety of the Vietnam War. The recommendations of the Study Group were taken and implemented accordingly. The method of implementation was a series of National Security Action Memorandums whose implications would reach deep into the central highlands of South Vietnam through the implementation of the CIDG.

President Kennedy privately "castigated the Joint Chiefs as "[t]hose sons-of-bitches with all the fruit salad [who] just sat there nodding, saying it would work," and "those CIA bastards" whose office I would like "to splinter" into "a thousand pieces and scatter...to the winds." ${ }^{59}$ The president, with the conclusion and recommendations of the CSG in hand, approved the publishing of NSAM 55, 56 and 57 on June 28, 1961 to accomplish these recommendations. NSAM 55 placed responsibility for both conventional and paramilitary operations under the JCS. NSAM 56 tasked the JCS to conduct an assessment of its paramilitary and unconventional warfare capabilities. NSAM 57 created the Strategic Resources Group to retain control of the paramilitary operations detailed in NSAMs 55 and 56. The three of these NSAMs changed the course of the Special Forces and conventional force operations throughout the Vietnam War by enabling conventional force commanders to apply conventional answers to unconventional problems and then task unconventional forces as they saw fit to accomplish them.

NSAM 55 was the official document that placed equal responsibility for conventional and paramilitary operations under the JCS. NSAM 55 was the lengthiest of the three memorandums and relays verbatim the findings of Recommendation 4 of the CSG. It charged them to conduct

\footnotetext{
59 Jones, The Bay of Pigs, 131.
} 
the operations in the recommendation, stating that the president regarded the JCS to be more than military men, but contributors in tackling what he called the most difficult problem in government, which was how to combine the myriad assets into a unified, effective operation. The document officially placed this power within the hands of individuals that had been alienated by his previous reforms and was meant to define the relationship as well as mend the fences within the ' for future Cold War program execution. President Kennedy was adamant about continuing Cold War programs of limited scale and covert nature, including further operations against communist Cuba, and had learned from the Bay of Pigs that he would need the JCS in order to conduct those programs.

NSAM 56 was President Kennedy, through National Security Adviser McGeorge Bundy, telling these same individuals and departments that the responsibility had been given, it was then incumbent upon the organization to get the house in order. This memorandum, in a single paragraph, ordered the JCS and other departments with stakes in paramilitary operations to conduct a full assessment of their capabilities to conduct paramilitary operations. In NSAM 55, responsibility was delegated for these operations, in NSAM 56, the president issued guidance to prepare for these future operations. A major problem in the Bay of Pigs failure was the disparate resourcing and compartmentalization of both knowledge and expertise. In this memo, the president told each department that the failings of the Bay of Pigs would not occur again due to lack of knowledge within the organization.

NSAM 57 created the apparatus to ensure that NSAM 55 and 56 were executed. It tasked “the Special Group (5412 Committee)” to “perform the functions assigned in the recommendation to the Strategic Resources Group.” By creating this group, utilizing the nomenclature of the National Security Council memorandum 5412, “one of the most secret documents in the US 
Government," ${ }^{60}$ authorizing the CIA to conduct paramilitary operations, the president was explicitly placing authority for these operations beneath this single apparatus. Special group 5412 "set up a permanent committee of representatives of under-secretarial rank from State, Defense and CIA under a full-time chairman reporting directly to the president" to "guide and coordinate Cold War strategy.” ${ }^{61}$ The president would no longer have multiple organizations conducting multiple operations of differing size, scope and intent, all such operations would be under the scrutiny of this single entity.

These NSAMs were issued the same day and put the CSG findings into action placing responsibility for the conduct of paramilitary operations firmly under a single entity. NSAM 55 designated responsibility for the conduct of these operations. NSAM 56 told those responsible to get ready to lead them. NSAM 57 created the Strategic Resources Group to lead them. The Bay of Pigs failure caused the president to decide that all large size CIA operations would be moved to the DoD for a higher level of fidelity of military advisory and control, rather than continuing to enable CIA planning and execution in a vacuum and without the resources to conduct the full operation they have planned without conventional military air, navy or ground support. In this environment, when Secretary McNamara was presented with the need to amplify support to the CIA's CIDG program, he was obliged to place it within the realm of the DoD, via the MACV, in order to maintain complete control over it. These memorandums dictated the policy that would be the key component in building the momentum for Secretary McNamara, the CIA, and the JCS to blithely acquiesce to move the CIDG from the CSD to the CIA at the July 1961 Honolulu Conference.

The policy that resulted from the Bay of Pigs failure was responsible for the future move

\footnotetext{
${ }^{60}$ Aguilar, Operation Zapata, 55.

${ }^{61}$ Ibid., 45.
} 
of operational control of the CIDG; the findings of the CSG were the root cause. These finding were codified in recommendation number 2, with the express assignment of paramilitary operations requiring significant military personnel exceeding CIA capabilities be transferred to the DoD. ${ }^{62}$ It was implemented through a series of NSAMs, NSAM 57 creating the single supervisory entity, which gave the power of the recommended SRG to the existing Committee 5412. At the Honolulu Conference the CIA would ask for additional resources and manpower to continue their counterinsurgency experiment in the Citizens Irregular Defense Group, and would, due to these reforms, have that program removed from their control.

The failure of the Bay of Pigs invasion caused further distrust between the president and both the JCS and CIA because the president believed he had received poor military guidance from the JCS. The president believed that the CIA had sold him a half-complete plan from the previous administration on the premise that it had to be continued or scrapped completely. Presidents Kennedy used a small group of advisers for national level military decision-making, including the JCS only after the decision to invade had been made. As such, the JCS's reaction was to intercede with large-scale air, ground and sea conventional forces on behalf of the beleaguered US-sponsored Cuban liberation forces on the beachhead, completely at odds with the president's proclivity for special operations forces and desire to retain deniability of responsibility for the attack. ${ }^{63}$ The CIA became suspect because the Bay of Pigs invasion had been a strictly CIA operation with special operations DoD personnel assigned, but without JCS or DoD oversight of their activities. The secretary's removal of the JCS intelligence office within the $\mathrm{OCB}^{64}$ during the purge of the NSC removed the apparatus to conduct effective intelligence integration and coordination for the operation until too late. The failure and subsequent

\footnotetext{
62 Aguilar, Operation Zapata, 48.

${ }^{63}$ McMaster, Dereliction of Duty, 6.

${ }^{64}$ Ibid., 67.
} 
assumption of responsibility for the failure by the president served to drive a bigger wedge into an already strained relationship and led the president to hold "a poor opinion about the judgment of many of the senior military leaders in the Pentagon." 65 This wedge would continue to grow as the president and his advisors low opinion of the JCS was further reinforced and strengthened by the successful conclusion of the Cuban Missile Crisis.

\section{The Gap Widens: Effects of the Cuban Missile Crisis}

The Cuban Missile Crisis, the first standoff between nuclear powered adversaries in history, resulted in further distancing of President Kennedy and his administration from the military leadership of the JCS, creating the perception that the president and his advisors had resolved the crisis "in spite of" the JCS best military advice, not through it. The JCS was further distanced from the president and his administration following the Cuban Missile Crisis because the president created the ExCom to exclude all but the Chairman of the JCS from decisionmaking organizations, the same group of individuals from the Bay of Pigs overcame their groupthink to successfully conclude the crisis, resulting in the reinforcement of their beliefs that the advice of the JCS would be simplistic and militaristic, without consideration of national nonmilitary objectives, following the successful non-military conclusion to the crisis. The perception of military ineptitude that would arise from the successful conclusion of this crisis would color the Kennedy administration's attitude toward the conduct of the Vietnam War, exemplified by the continuation of the policy to exclude the JCS following President Kennedy's death that earned them the nickname the "five silent men." 66

The president, still reeling from Bay of Pigs “betrayal,” excluded the JCS and formed a

\footnotetext{
${ }^{65}$ Cosmas, The Joint Chiefs of Staff and The War in Vietnam - 1960-1968 Part 1 (History of the Joint Chiefs of Staff), 253.

${ }^{66}$ Lederman, Reorganizing the Joint Chiefs of Staff, 26.
} 
group called the ExCom to deliberate and decide upon the course of action for the Cuban Missile Crisis. "A group that included the Secretary of the Treasury, four senior members of the State Department, and three senior civilians of the Defense Department, among others, only one professional military officer was present - General Maxwell D. Taylor...the newly serving Chairman of the Joint Chiefs of Staff." 67 The JCS had not been allowed to inform the president of their opinions, but given GEN Taylor as a go between that they were not convinced could adequately state their cases. ${ }^{68}$ The JCS were finally given a meeting with the president following many attempts by GEN Taylor to convince him that his job as Chairman would be infinitely easier if he heard them out. ${ }^{69}$ The president conducted an exasperated meeting with the JCS in which he listened in growing annoyance to each of their military assessments. Following their reports, the president announced, with the support of the ExCom, that he had already decided upon a blockade, and it was their job to support it. He had little faith in their ability to understand the potentially escalatory consequences of their actions, but "if the JCS had been present during the ExCom's deliberations, they would have been able to reassure the president that the military would be able to follow carefully his decisions....without overreacting and escalating the confrontation.”70

President Kennedy realized that the decision process he had used for the Bay of Pigs invasion had been flawed. The president and his chosen advisors made conscious efforts to correct the mistakes of that process. The president and his advisors corrected the problems of the Bay of Pigs groupthink decision process by encouraging dissension within the group to create a new group norm, and instituting the antithesis of groupthink in the form of a vigilant appraisal of

\footnotetext{
${ }^{67}$ Barlow, “President John F. Kennedy and His Joint Chiefs of Staff,” 201.

${ }^{68}$ Ibid., 175-200.

69 Taylor, Swords and Plowshares, 269.

${ }^{70}$ Barlow, "President John F. Kennedy and His Joint Chiefs of Staff,” 217.
} 
all decisions made. ${ }^{71}$ The ExCom instituted a plan to counter their previous mistakes. They changed to new definitions of each participant's role, moving each member outside of their comfort zone to create a learning atmosphere of equality between each. Further, in the attempt to change the group atmosphere and continually create new dynamics, they conducted sub group meetings and leaderless sessions at which ideas and disagreements could be fully addressed. Throughout these sessions, they also agreed to acknowledge the grave danger of every decision made, explicitly discussing the moral implications involved, ensuring that should individuals still maintain reservations they would understand completely the price of their silence. The ExCom allowed reversals of judgment without penalty, further supporting a learning rather than defensive environment. "The key members of the Executive Committee who so successfully avoided succumbing to groupthink tendencies-the President, the Attorney General, the White House coordinator, the Secretary of State, the Secretary of Defense, and several other high-ranking officials-were the same individuals who had formed the nucleus of the group that eighteen months earlier had shown all the symptoms of groupthink when planning the Bay of Pigs invasion.”72 The failure at the Bay of Pigs may have saved the world from a nuclear war, having been a clear example of how not to conduct business, the same group of men were able to confront the Cuban Missile Crisis by consciously not re-making the same mistakes that had doomed the Bay of Pigs to failure. In the future, the reformed group that had successfully escaped groupthink to solve a complex problem, including Secretary McNamara and the Chairman of the JCS GEN Maxwell Taylor. This success would lead these individuals to conclude that they did not necessarily need the JCS to make national military decisions after all, creating an atmosphere in which Secretary McNamara could follow the institutional inertia against the JCS created by the

\footnotetext{
${ }^{71}$ Janis, Groupthink, Ch.6.

${ }^{72}$ Ibid., 158.
} 
Bay of Pigs and Cuban Missile Crisis in the future when it came to the control of paramilitary operations in Vietnam.

The president's lack of confidence in the JCS was translated to the civilian leadership of the DoD as exemplified in by their belief that the JCS couldn't be trusted to not leak secret information and their dismissal of the military chain of command as irrelevant. The president's “excessive concern with secrecy kept his Unified Commander from knowing the details of the ExCom's decision-making even as the Admiral was preparing his forces to execute the President’s directives.” ${ }^{, 73}$ In a blatant example of institutional disrespect by the New Frontiersman civilian leadership, Deputy Defense Secretary Gilpatric did not feel it necessary to inform the Chief of Naval Operations of the movement of one his squadrons from Oceana, Virginia to Key West, FL while placing them temporarily under Air Force control. Mr. Gilpatric simply bypassed the chain of command and called the Admiral in charge of the squadron directly to give the order. Clearly, the administration's biases against the JCS were being enacted throughout the crisis, as they were kept out of the information loop and bypassed by civilian leadership. “One major obstacle--not objection, but obstacle--to a blockade was that the JCS still wanted an air strike or an invasion. The president met with the chiefs...and came out of the meeting visibly annoyed.”74 Secretary McNamara didn't feel it necessary to be an expert in combat leadership in a situation like Cuba, thus, felt like the president that it was unnecessary to have the JCS direct input in decision-making. ${ }^{75}$ The consequence of these actions was the realization of the self-fulfilling prophecy that the JCS was irrelevant following the successful conclusion of the crisis in which they were perceived to have played little part. The president and secretary's perceptions of the

\footnotetext{
73 Barlow, "President John F. Kennedy and His Joint Chiefs of Staff,” 206. 1996), 102.

${ }^{74}$ Roger Hilsman, The Cuban Missile Crisis: The Struggle over Policy (Westport, CT: Praeger,

${ }^{75}$ Barlow, “President John F. Kennedy and His Joint Chiefs of Staff,” 208.
} 
JCS as juvenile and wholly incapable of thinking outside of militaristic outcomes were reinforced by the advice they had received throughout the crisis. Regardless of the exclusion of those individuals from the meetings at which their advice may have been extremely helpful, the ExCom muddled through and were successful, reinforcing their belief that the JCS had not been necessary to begin with.

\section{Practical Application Supports Movement}

The transfer of the CIDG and other paramilitary activities to MACV control was inevitable, despite widespread apprehension in CIA that this would result in distorting the programs' respective missions. The Directorate of Plans...lacked the personnel and organizational resources to manage activities of this size without serious erosion of its ability to conduct worldwide intelligence collection and covert action operations.

-Thomas L. Ahern, Vietnam declassified: the CIA and counterinsurgency

The political and governmental dimensions greatly influenced the decision for control of the CIDG program, however, also of great significance were the practical issues involved in conducting an operation of the planned importance and magnitude of the CIDG would require a robust support mechanism to continue to be effective. The CIDG was moved to DoD MACV control due to the practical implications of the program's exponential short-term growth in size and importance because of the Kennedy administration's policy change from escalation to withdrawal, the Strategic Hamlet Program being behind schedule, and the exponential growth of the program grossly exceeding the CIA's ability to support it. The conclusion to move the program succeeded in ensuring that the administrative and logistical problems of the program would be under the direct supervision and receive all necessary support from the unified military command of South Vietnam.

President Kennedy had never been of the opinion that large-scale military operations within Southeast Asia would lead to success, as evidenced by his actions during the Laotian 
crises, which was considered a higher threat and priority by the administration. ${ }^{76}$ President Kennedy was presented with two options by the JCS, large-scale intervention of an indeterminate duration or maintaining a militarily neutral position while brokering a resolution through a peace treaty. He chose the latter alternative. ${ }^{77}$ As such, the president determined that, after an initial ramp-up of advisory support, the policy for the United States long-term involvement in South Vietnam was for advisory and limited troop presence; Secretary McNamara conducted execution of that policy through monthly conferences with all parties in Honolulu, Hawaii. As advisory needs and recommendations by the MACV to the JCS continued to escalate in scale and scope it was necessary for the SecDef to remind military leadership "that the purpose of the United States assistance was "to help the Vietnamese fight their war and to reduce, not increase our own combat role.” The Strategic Hamlet program, and the other experimental paramilitary Pacification programs being conducted in parallel, were designed to utilize indigenous personnel to secure the South Vietnamese rural population from NLF coercion. The Strategic Hamlet program re-settled the population of areas of great insurgent influence into villages that were contained within defensible boundaries firmly under GVN control. These programs were denying the insurgency the human terrain it needed to survive and were the best method for the United States to continue involvement in stopping the insurgency in Vietnam while de-escalating the number of US forces in the country. The Strategic Hamlet Program was determined by both the US Mission and GVN to be of the utmost importance in securing the populace from the NLF, however, the resources in manpower, training and equipment were scarce, especially when facing the policy of withdrawal designated by the president who had stated "that he wanted to not only hold the level of US

\footnotetext{
${ }^{76}$ Cosmas, The Joint Chiefs of Staff and The War in Vietnam - 1960-1968 Part 1 (History of the Joint Chiefs of Staff), Ch.2.

${ }^{77}$ Ibid., Ch.2-3.
} 
military presence in Vietnam down, but he wanted to reverse the flow.”,78

In mid-year 1962 "both the North Vietnamese on one side and the South Vietnamese with their American advisors on the other viewed the strategic hamlets as the strategic center of the war.”79 At the July 1962 Honolulu Conference it was determined that the Strategic Hamlet program, the primary method of Pacification at the time, was a year behind schedule and it was estimated it would be a full three years before the program would successfully bring the VC threat under control. ${ }^{80}$ The administration's major problem with this assessment was the tactical requirement to retain the current level of involvement, or increase it, did not match the strategic policy aim of withdrawal and de-escalation of United States military support within the desired amount of time. The US Army had already deployed 9,069 military personnel to Vietnam, which included eleven Special Forces teams and eighty American-manned helicopters. ${ }^{81}$ The US Air Force Jungle Jim Squadron now numbered sixteen fixed-wing propeller-driven aircraft including four C-47 transports. ${ }^{82}$ In order to maintain the policy of withdrawal, a solution would have to be found to increase the efficacy of programs to influence the populace while decreasing the number of US personnel and equipment in South Vietnam. There were two concurrent programs running in this vain, the Citizens Irregular Defense Group and the Strategic Hamlets Program. The former was a CIA program using Special Forces to train and equip rural indigenous forces in the central highlands for self-defense, the latter a CIA and GVN program being administered by the brothers of GVN President Ngo Dinh Diem throughout the Mekong Delta and southern provinces. The administration of the GVN was poorly orchestrated and contributed greatly to the inefficacy of

${ }^{78}$ David E. Kaiser, American Tragedy: Kennedy, Johnson, and the Origins of the Vietnam War (Cambridge, MA: Belknap Press of Harvard University Press, 2000), 140.

${ }^{79}$ Special Group for Counterinsurgency, "Minutes of Meeting of the Special Group for Counterinsurgency”, April 4, 1963, Doc. No. 78.

${ }^{80}$ Cosmas, The Joint Chiefs of Staff and The War in Vietnam - 1960-1968 Part 1 (History of the Joint Chiefs of Staff), 250.

${ }^{81}$ Ibid., 248.

${ }^{82}$ Ibid. 
the approach. Following the coup against President Diem, the Strategic Hamlet Program was scrapped, but the CIDG, being a CIA project, survived the purge of Diem’s programs that followed his death. ${ }^{83}$ The CIDG was about to grow exponentially beneath the weight of policy and the need to affect the populace in the manner of the now absent Strategic Hamlet Program. CIA limitations on manpower required military augmentation. The CIA did not have the capacity to conduct its assigned national intelligence function as well as administer the CIDG; "when it assigned covert action responsibilities to the CIA in the spring of 1961, the new Kennedy Administration had probably not contemplated the arming of almost 40,000 men." ${ }^{84}$ The logistical requirements for this program had required flexibility inherent in the CIA that was not reproducible in the MACV. As such, the CIA retained monetary and specialized logistical support for the Special Forces troops, while the MACV assumed distribution of the logistical assets this money procured through its more robust command and logistical support systems. ${ }^{85}$ "By the end of 1962....6000 strike force troops and 19,000 village defenders and hamlet militia had been trained. Other irregulars trained included 300 border surveillance troops, 2,700 mountain scouts, and approximately 5,300 Popular forces troops.” ${ }^{86}$ Not only was additional logistical support required, but the provisional Special Forces Headquarters was upgraded to the $5^{\text {th }}$ Special Forces Group Headquarters within the MACV, with OPCON of Special Forces Operational Detachment Alpha Teams (SFODA) being retained by the MACV Corps Senior Advisors in each Corps Tactical Zone through the SFODB's attached to them. ${ }^{87}$ This program was intended to be a “carefully conceived long-range” training and equipping program that would involve the "phase

${ }^{83}$ Ahern, Vietnam Declassified, 90.

${ }^{84}$ Ibid., 91.

${ }^{85}$ Ibid., 115.

${ }^{86}$ Kelly, Bowers, and Army, U.S. Army Special Forces 1961-1971, 37.

${ }^{87}$ US Army, "Outline History of the 5th SF Gp (Abn) Participation in the CIDG Program 19611970” (US Army Military History Institute, n.d.), 3. 
out of major United States combat advisory and logistics support activities.” ${ }^{\text {" }}$ It accomplished this, however, as a side effect, it also gave control to the conventionally focused MACV command which resulted in the immediate change of the CIDG mission from population and terrain retention through pacification to offensive operations in support of conventional force commanders.

The practical need to implement this policy was not disputed. Under the policy of withdrawal, following the death of President Diem in the coup, the CIDG was estimated to be the best chance the United States had to enable the South Vietnamese to defend themselves with the smallest footprint in both men and arms. The drawback to the plan was time and the belief that popular support for these actions would wane by the time the program came to fruition. The decision to accelerate the process and place the CIDG beneath an apparatus that could adequately support the system was inevitable, however would have far-reaching consequences for the entirety of the mission in South Vietnam.

The CIDG movement, which even included a name change, from Citizen to Civilian ${ }^{89}$ Irregular Defense Group, reflecting the conventional military’s disdain for the program as nonmilitary. A combination of political and practical impetus caused the movement of an unconventional program to a conventional command structure. The political reasons were based in control. The practical reasons were based in time and resources. The effect of this movement was to impact the Special Forces, conventional MACV military, and CIA profoundly throughout the duration of the war.

\footnotetext{
${ }^{88}$ Cosmas, The Joint Chiefs of Staff and The War in Vietnam - 1960-1968 Part 1 (History of the Joint Chiefs of Staff), 250.

${ }^{89}$ William Egan Colby, Lost Victory: A Firsthand Account of America's Sixteen-Year Involvement in Vietnam (Chicago, IL: Contemporary Books, 1989), 166.
} 


\section{CONCLUSION}

The country-wide CIDG Program was transferred to COMUSMACV from CAS on 1 July 1963. It has not lived up to expectations. The program has changed in concept from one designed to recover people and terrain from VC domination to one of killing VC. This reorientation has lost sight of the population as a target and is focused entirely on the VC.

—LTC H.H. Knight, Report on Forrestal Group Trip to SVN - 19 Nov - 7 Dec 1964

Why did it happen?

Operation Switchback occurred because of the distrust that existed between the Kennedy administration and the senior military leadership. The Kennedy administration immediately acted to remove the power of the NSC and the JCS through the process of agenda-framing by reducing staff and removing key committees that enabled the JCS to have a direct line to the president. The Bay of Pigs and Cuban Missile Crisis cemented the president and secretary's perception of JCS incompetence and the need for strong civilian control of the military, leading to the implementation of policy that would specifically direct the movement of the CIDG from CIA to DoD operational control. The Bay of Pigs led them to believe they had been misled by incompetents, within the JCS and CIA both, that could not do what they said they could and who had not shared the president's vision of truly a non-attributable revolution in Cuba. The successful resolution of the Cuban Missile Crisis led them to the belief that one did not need to be a military expert to solve a military problem and that the JCS and CIA simply could not understand national policy decisions outside of their specific frames of mind. Within this narrative of civil-military-intelligence political maneuvering and distrust, the conflict in Vietnam was being fought through United States-led training and pacification efforts. The CIDG was the most successful of these programs and it was growing beyond the capacity of the CIA to manage. The practical implications of the CIA's inability to manage the most successful and fastest growing program that focused directly upon and accomplished the administration's de-escalation and COIN-centric policy for Vietman, led Secretary McNamara to quickly and easily decide to change operational control of the CIDG from an agency which he did not trust or directly control 
to one that he also may not have entirely trusted, but over which he maintained direct control. Institutional inertia was cited by former CIA officer, NSC member and CORDS program director Robert Komer as the primary reason for the switch. ${ }^{90}$ The CIA viewed it as inevitable, and grumbled that it could very well be disastrous for the program itself. ${ }^{91}$ However, unrelated and seemingly irrelevant events built into a cascade that made this far-reaching decision seem like a simple and practical solution to a simple practical problem, with consequences that reverberated until Saigon’s fall on April 30, 1975.

\section{What can we learn from it?}

Right Tool for the Right Job: What are the potential dangers of using the US Special Forces exclusively for Special Reconnaissance, Direct Action and offensive Combat Foreign Internal Defense under conventional military leadership?

The effects of the change in operational control of the CIDG marginalized and misapplied the strengths of a specialized organization. The change was not grounded in doctrine or measures of military effectiveness, but in the political perceptions and rivalries between the civilian and military leadership at the national level. The lesson for commanders and planners is in understanding the operational environment not only of the assigned mission, but of the headquarters that has given it. The complex system that drives operations includes both internal and external mechanisms that are interested first with individual survival and second with mission accomplishment. Understanding this, through this example, can inform future leaders to bind major muscle movements to measures of effectiveness bound in military analysis, or following a situation out of their control, inform the argument against continuation of the policy. It can also

\footnotetext{
${ }^{90}$ Komer, Bureaucracy at War, 70.

${ }^{91}$ Ahern, Vietnam Declassified, 91.
} 
inform long-term decisions regarding internal political benchmarks, like elections, as military planners move forward in planning an operational approach to achieve a strategic aim. 


\section{BIBLIOGRAPHY}

Aguilar, Luis. Operation Zapata: The "Ultrasensitive” Report and Testimony of the Board of Inquiry on the Bay of Pigs. Frederick, MD: Aletheia Books, 1981.

Ahern, Thomas L. Vietnam Declassified: The CIA and Counterinsurgency. Lexington, KY: University Press of Kentucky, 2010.

Army Concept Team in Vietnam. “Employment of a Special Forces Group”, April 20, 1966.

Barlow, Jeffrey G. "President John F. Kennedy and His Joint Chiefs of Staff”. University of South Carolina, 1981.

Cambone, Stephen A. A New Structure for National Security Policy Planning. Significant issues series 20, no. 3. Washington, DC: CSIS Press, 1998.

Colby, William Egan. Lost Victory: A Firsthand Account of America's Sixteen-Year Involvement in Vietnam. Chicago, IL: Contemporary Books, 1989.

Cosmas, Graham A. The Joint Chiefs of Staff and The War in Vietnam - 1960-1968 Part 2 (History of the Joint Chiefs of Staff). CreateSpace Independent Publishing Platform, 2013.

Cosmas, Graham A., and Center of Military History. MACV: The Joint Command in the Years of Escalation, 1962-1967. Military Bookshop, 2011.

Cosmas, Graham A., and US Army Center of Military History. MACV: The Joint Command in the Years of Withdrawal, 1968-1973. Military Bookshop, 2008.

Frank, Richard B. Downfall: The End of the Imperial Japanese Empire. New York, NY: Penguin, 2001.

Hilsman, Roger. The Cuban Missile Crisis: The Struggle over Policy. Westport, CT: Praeger, 1996.

- To Move a Nation: The Politics of Foreign Policy in the Administration of John F. Kennedy. New York, NY: Dell Publishing Co., 1964.

Ives, Christopher K. US Special Forces in Counterinsurgency in Vietnam: Military Innovation and Institutional Failure, 1961-63. London: Routledge, 2012.

Janis, Irving L. Groupthink: Psychological Studies of Policy Decisions and Fiascoes. 2nd ed. Boston, MA: Houghton Mifflin, 1982.

Jones, Howard. The Bay of Pigs. Pivotal moments in American history. Oxford, NY: Oxford University Press, 2008.

Kaiser, David E. American Tragedy: Kennedy, Johnson, and the Origins of the Vietnam War. Cambridge, MA: Belknap Press of Harvard University Press, 2000.

Kelly, Francis J., Verne L. Bowers, and U. S. Department of the Army. U.S. Army Special Forces 1961-1971. MilitaryBookshop.co.uk, 2011.

Kennedy, John F. "Democratic National Convention Nomination Acceptance Address 'The New Frontier'”, Memorial Coliseum, Los Angeles, CA, July 15, 1960.

Knight, H.H. “'Report on Forrestal Group Trip to SVN - 19 Nov - 7 Dec 1964,””. Office of the Special Assistant for Counterinsurgency and Special Activities Programs \& Review Division, n.d.

Komer, R. W. Bureaucracy at War: U.S. Performance in the Vietnam Conflict. Westview special studies in national security and defense policy. Boulder, CO: Westview Press, 1986. . "Impact of Pacification on Insurgency in South Vietnam", Presentation at the Biltmore Hotel, Los Angeles, California, September 8, 1970.

Kotter, John P. Power and Influence. New York, NY: Free Press, 1985.

Krepinevich, Andrew F. The Army and Vietnam. Baltimore, MD: Johns Hopkins University Press, 1988.

Lederman, Gordon Nathaniel. Reorganizing the Joint Chiefs of Staff: The Goldwater-Nichols Act 
of 1986. Contributions in military studies no. 182. Westport, CT: Greenwood Press, 1999. McMaster, H.R. Dereliction of Duty. New York, NY: HarperPerennial, 1997.

Nye, Joseph S. The Future of Power. New York, NY: PublicAffairs, 2011.

Piasecki, Eugene G. “Civilian Irregular Defense Group: The First Years: 1961-1967.” Veritas 5, no. 4 (2009).

Rearden, Steven L. Council of War: A History of the Joint Chiefs of Staff, 1942 - 1991. Washington, DC: NDU Press for the Joint History Office, Office of the Director, Joint Staff, Joint Chiefs of Staff, 2012.

Sorensen, Theodore C. Decision-Making in the White House: The Olive Branch or the Arrows. Columbia classics. New York, NY: Columbia University Press, 2005.

Special Group for Counterinsurgency. "Minutes of Meeting of the Special Group for Counterinsurgency”, April 4, 1963. Doc. No. 78.

Taylor, Maxwell D. Swords and Plowshares. 1st ed. New York, NY: W. W. Norton, 1972.

US Army. "Outline History of the 5th SF Gp (Abn) Participation in the CIDG Program 19611970”. US Army Military History Institute, n.d.

—. "The GVN CIDG Political Action Program 1965”. History of the Vietnam War on Microfilm, March 3, 1965.

US Army War College. “The US Army Role in Counterinsurgency, US Army War College Curriculum”. Carlisle Barracks, Pennsylvania, 1961.

Webb, Del. “The Pentagon's Whiz Kids.” Time Magazine LXXX No. 05 (August 3, 1962).

Willbanks, James H. Abandoning Vietnam: How America Left and South Vietnam Lost Its War. Lawrence, KS: University Press of Kansas, 2004.

Zegart, Amy B. Flawed by Design: The Evolution of the CIA, JCS, and NSC. Stanford, CA: Stanford University Press, 1999. 